NBER WORKING PAPER SERIES

\title{
SOCIAL FRAGMENTATION, PUBLIC GOODS AND ELECTIONS: EVIDENCE FROM CHINA
}

\author{
Gerard Padro i Miquel
}

Nancy Qian

Yang Yao

Working Paper 18633

http://www.nber.org/papers/w18633

\author{
NATIONAL BUREAU OF ECONOMIC RESEARCH \\ 1050 Massachusetts Avenue \\ Cambridge, MA 02138 \\ December 2012
}

We acknowledge financial support from NSF Grant no. 0922087 for the collection of the Village Democracy Surveys (2006, 2011), the Yale University EGC Faculty Grant and the European Union's Seventh Framework Programme (FP/2007-2013) / ERC Starting Grant Agreement no. 283837. The views expressed herein are those of the authors and do not necessarily reflect the views of the National Bureau of Economic Research.

NBER working papers are circulated for discussion and comment purposes. They have not been peerreviewed or been subject to the review by the NBER Board of Directors that accompanies official NBER publications.

(C) 2012 by Gerard Padro i Miquel, Nancy Qian, and Yang Yao. All rights reserved. Short sections of text, not to exceed two paragraphs, may be quoted without explicit permission provided that full credit, including $(\subset$ notice, is given to the source. 
Social Fragmentation, Public Goods and Elections: Evidence from China

Gerard Padro i Miquel, Nancy Qian, and Yang Yao

NBER Working Paper No. 18633

December 2012

JEL No. O38,O43,P16,P35

\section{ABSTRACT}

This study examines how the economic effects of elections in rural China depend on voter heterogeneity, for which we proxy with religious fractionalization. We first document religious composition and the introduction of village-level elections for a nearly nationally representative sample of over two hundred villages. Then, we examine the interaction effect of heterogeneity and the introduction of elections on village-government provision of public goods. The interaction effect is negative. We interpret this as evidence that voter heterogeneity constrains the potential benefits of elections for public goods provision.

Gerard Padro i Miquel

STICERD

London School of Economics

Houghton Street

London, WC2A 2AE

UNITED KINGDOM

and NBER

g.padro@lse.ac.uk

Nancy Qian

Department of Economics

Yale University

27 Hillhouse Avenue

New Haven, CT 06520-8269

and NBER

nancy.qian@yale.edu
Yang Yao

China Center for Economic Research

Peking University

Peking, China

yyao@ccer.pku.edu.cn 


\section{Introduction}

A central question for economists, political scientists and policymakers is why the introduction of democracy in developing countries during the 20th century has so often failed to produce the public policy changes that Western European countries historically experienced when they democratized (e.g. Acemoglu and Robinson, 2000; Lizzeri and Persico, 2004). One potential answer, as argued by the modernization (Lipset, 1959) and the critical junctures hypotheses (Acemoglu et al., 2008), is that democracy can only survive and succeed in contexts where certain historical pre-conditions exist. However, existing studies provide little concrete evidence on what the exact pre-conditions are and which economic outcomes are sensitive to these conditions. This paper addresses this gap in the literature by examining how the introduction of village elections interacts with voter fragmentation, defined as the clustering of citizens in different groups with potentially distinct identities, in determining the allocation of government-provided public goods in rural China.

Village elections were introduced during the 1980s and 1990s to address challenges in local governance that had led, among other problems, to severe under-provision of public goods in rural China. These elections partially replaced the Communist Party-appointment system that had previously determined village leadership and represent a marginal shift towards democracy in village government. ${ }^{1}$ Consistent with the belief that electoral accountability incentivizes village leaders to improve public goods provision, several recent studies have found that the introduction of elections increased average local public goods provision in a way that corresponded to the demand of villagers (e.g., Luo et al., 2007, 2010; Martinez-Bravo et al., 2012; Mu and Zhang, 2011; Zhang et al., 2004). These results on the average effect of elections together with the size and diversity of China's social-geographic landscape makes China a natural context for studying the relationship between the underlying heterogeneity in villages and the effectiveness of elections in determining public goods.

A priori, the interaction of heterogeneity and elections on government-provided public goods is ambiguous. A number of factors suggested in the literature (i.e. lack of trust and altruism, preference divergence, conflict between groups) can cause social fragmentation to reduce the government's ability and willingness to raise revenues to provide public goods his literature, reviewed

\footnotetext{
${ }^{1}$ See Section 2 for a more detailed discussion and references.
} 
in. ${ }^{2}$ This negative relationship should in principle hold for both appointed and elected governments. Hence, the sign of the interaction depends on whether this relationship is stronger under an elected government than under an appointment one. For instance, if fragmentation limits the benefits of elections because it weakens electoral accountability, the interaction would be negative. In contrast, if heterogeneous villages have more to gain from the introduction of elections because elections aggregate conflicting preferences, the interaction would be positive. Therefore, whether the effects of elections are larger or smaller in heterogeneous polities is ultimately an empirical question.

There are two main challenges in studying the interaction effect of democratization and voter heterogeneity on public goods provision: identification and data. The main concern for identification is that voter heterogeneity is correlated with other factors (such as a history of conflict or weak administrative capacity) that could influence whether elections are implemented, as well as the effect of elections on public goods. Similarly, voter heterogeneity could be an outcome of democratization. For example, across countries, if democracies are more tolerant of diversity and are better able to provide public goods for reasons unrelated to diversity, the sign of the interaction effect would not necessarily reflect whether heterogeneity is an important pre-condition for a working democracy.

The second difficulty is finding high quality data from the appropriate context. A study on the interaction effects of voter heterogeneity and the introduction of elections, or any democratization reforms, requires a context that fulfills the following criteria: $i$ ) the units of observation must be responsible for determining and financing public goods; ii) these units must undergo a similar and well-defined shift towards democracy; iii) there must be variation in voter heterogeneity across the populations in these units; iv) the introduction of democracy should be exogenous with heterogeneity; and $v$ ) these units should be otherwise similar so that they are comparable for statistical analysis. While cross-national analyses struggle with ii), iv) and $v$ ), within-country comparisons tend not to satisfy i) and ii). The introduction of village-level elections in China and the natural variation in local population mixes across this large country provides a context in which both of these difficulties can be successfully addressed.

Our study proceeds in two steps. First, we document the introduction of elections, public goods expenditures and provision, and social composition of villagers in each village for a nearly nationally

\footnotetext{
${ }^{2}$ There is a large literature that finds a negative relationship between social heterogeneity and public goods in different contexts. Please see the discussions towards the end of the introduction and in Section 3.
} 
representative sample of over two hundred villages and twenty years. The Village Democracy Survey (VDS), the main source of the data, is a unique survey conducted by the authors that digitized data from village records. This dataset is supplemented with demographic variables from the National Fixed Point Survey (NFS), which is collected by the Ministry of Agriculture each year in the same villages as the VDS.

For practical reasons, we focus on religious fragmentation as a proxy of voter heterogeneity. Of the three dimensions of ethnic, religious and linguistic fragmentation that dominate the literature on diversity, religion is the only one that varies substantially across the villages in our sample. The re-emergence of religion after years of state repression is also interesting as it has received little attention from researchers so far, and because religious fragmentation has been shown to be important for economic performance in European countries (e.g., Alesina et al., 2003; Montalvo and Reynal-Querol, 2003) and the historical Chinese context (e.g., Weber, 1968), and for economic attitudes in the cross-country evidence (e.g., Guiso et al., 2003). ${ }^{3}$ Since religious conflicts are practically non-existent in our context, we interpret religious fragmentation broadly as a proxy for social fragmentation. In other words, our study will reveal the importance of religion as a dimension for social clustering in post-Mao rural China.

The second step is to use the data to examine the interaction effect of the introduction of elections, which varied in time across villages, and a time-invariant measure of the level of average religious fragmentation that varies across villages. ${ }^{4}$ Because data for religious population shares are not available every year, we use the average of religious fragmentation over time to maximize sample size. The baseline specification controls for village fixed effects, which absorb all timeinvariant differences across villages; year fixed effects, which control for all changes over time that affect all villages similarly, such as macro economic changes taking place in China during this period;

\footnotetext{
${ }^{3}$ We discuss the re-emergence of religion in rural China in section 2. We do not have reliable data for other dimensions of heterogeneity such as the education composition of villagers, and income is not a stable dimension of social clustering since elections caused significant income redistribution (Martinez-Bravo et al., 2012). Another potentially relevant dimension of heterogeneity in this context is kinship networks. However, several studies by sociologists find that extended kinship networks have become less important in China over time due to factors such as the collectivization of agriculture during the Maoist era and the rapid economic growth and social modernization that followed (e.g., Cohen, 1992; Jiang, 1995). For completeness, we will examine the influences of fragmentation along kinship lines and other sources of heterogeneity such as pre-election income after we present the main results on religious fragmentation.

${ }^{4}$ In most of the paper, we measure fragmentation by constructing an index of fractionalization. This particular choice of measurement is not important for our results, which are robust to using an alternative polarization index. This is shown and discussed in more detail later in the paper. See Alesina et al. (2003), Duclos et al. (2004), Esteban and Ray (2007) and Montalvo and Reynal-Querol (2003) for discussions of the different measures of fragmentation.
} 
and province-time trends, which control for the growing economic divergence across regions during the reform era. Our strategy is similar to a triple differences estimate that compares public goods in villages before and after the introduction of elections, between villages that have already introduced elections to those that have not, and between fragmented and less fragmented villages.

To address the fact that religious fragmentation is a non-random variable that is correlated with other factors that can influence elections and public goods, the baseline equation controls for correlates such as village population, the average share of religious population in the village interacted with year fixed effects, and most importantly, the interaction of average religious fragmentation interacted with the full vector of year fixed effects. The latter set of controls is extremely conservative as it controls for all differences across villages of different levels of fragmentation and allows these differences to matter over time in a fully flexible manner. It forces our estimates to be identified only from a systematic change in the difference in public goods between fractionalized and less fractionalized villages from the year that elections are implemented.

Our interpretation of the interaction effect relies on two assumptions. First, our measure of religious fragmentation must not be an outcome of elections. We support this by showing that elections have no effect on the time-varying measure of religious fragmentation, and that average religious fragmentation is uncorrelated with the timing of the introduction of elections. Second, we assume that, conditional on our baseline controls, the interaction of the introduction of elections and religious fragmentation is not jointly determined with public goods. In other words, we assume that fragmentation is not correlated with other factors (beyond the baseline controls) that can influence the effect of elections on public goods. This is highly unlikely since the baseline controls for the interaction of fragmentation and year fixed effects. Nevertheless, we do not take this as given and provide a large body of evidence against alternative explanations in the Robustness section. Note that the interpretation of the interaction effect as causal does not require that the timing in the introduction of elections was random.

The main results show that prior to the introduction of elections, village government expenditure on public goods was very similar across villages with different degrees of fragmentation; elections increase public goods expenditure, and the magnitude of the effect declines with fragmentation. We find similar results when examining proxies for public goods provision as the dependent variable, which supports our interpretation of expenditure as reflecting provision. Taken literally, the 
estimates imply that approximately $92 \%$ of the villages in rural China were homogenous enough to experience some increase in public goods expenditures after the introduction of elections, while $8 \%$ of villages were so heterogeneous that elections reduced village public goods expenditure. The high share of villages to experience some increase from elections is not surprising given the homogeneity of most Chinese villages.

In addition, we show that the changes in public goods expenditure occur exclusively for villageraised funds; we have no effect of elections or the interaction for public goods funded by the upper levels of government. Together with the large number of robustness checks we conduct, these results suggests that mechanisms local to the village are causing heterogeneous villages to experience lower gains from elections. In particular, there are two possible and non-mutually-exclusive mechanisms, both related to the fact that elections increase accountability: i) heterogeneous villages have a lower preference for public goods and elected village leaders reflect better this underlying preference or ii) homogeneous villages are better able to keep elected leaders accountable. ${ }^{5}$ Importantly, we are able to rule out the alternative explanation that our results are driven by poor implementation of the electoral reforms in fragmented villages by showing that there is no relationship between heterogeneity and the quality of election implementation.

Our study makes several contributions to the literature. It is the first to provide direct and rigorous empirical evidence on the interaction of formal institutional reform and pre-existing conditions. The results show that the presence of distinct groups in society can severely limit the effects of a democratic transition for public goods provision. Our study is most similar to a recent study by Bandiera and Levy (2010), which provides theoretical and empirical evidence that heterogeneity causes democratically elected local governments in Indonesia to implement policies that favor elites.

This study complements a large empirical literature studying the relationship between heterogeneity and public goods provision (e.g., Alesina et al., 1999; Alesina and La Ferrara, 2000, 2002, 2005). ${ }^{6}$ The object of our analysis differs in that we investigate how heterogeneity modulates the effects of institutional change on public goods instead of the cross-sectional effect of heterogeneity on public goods. In focusing on a developing country, we are most similar to Khwaja (2009), Okten

\footnotetext{
${ }^{5}$ Please see the discussion in Section 3.

${ }^{6}$ The seminal paper in the cross-sectional literature is Alesina et al. (1999), which generated a literature that is surveyed in Alesina and Ferrara (2005). Luttmer (2001) and Alesina and La Ferrara (2002) find that fragmentation affects preferences towards neighbors. See also Munshi and Wilson (2010) for an analysis of the origin and transmission of fragmentation in the United States.
} 
and Osili (2004) and Miguel and Gugerty (2005), which find that social fragmentation reduces collective action towards public goods in Pakistan, Indonesia and Kenya; and Banerjee et al. (2001), Banerjee and Somanathan (2007) and Munshi and Rosenzweig (2008), which examine how groups mobilize through the political system to obtain public goods in India. ${ }^{7}$ In focusing on religious fragmentation as our measure of heterogeneity, we contribute to the macro-empirical literature on the effect of religious fragmentation on growth (e.g., Alesina et al., 2003; Montalvo and Reynal-Querol, 2003).

We also add to the studies discussed earlier on Chinese elections by initiating research for understanding the pre-conditions for elections. Since the average effect reflects the conditions of a very specific context, an analysis of the pre-conditions is crucial towards obtaining generalizeable lessons for policymakers. Moreover, in the discussion of China's transition, religion has become an object of increasing academic interest and systematic data collection. ${ }^{8}$ To the best of our knowledge, we produce the first village-level dataset that documents regional religious composition during the modern era, which together with the other data we have collected, make a general contribution by facilitating future research on the relationship between informal and formal institutions and economic outcomes in China.

This paper is organized as follows. Section 2 discusses the background. Section 3 discusses the conceptual framework and the empirical strategy. Section 4 describes the data. Section 5 presents the results. Section 6 concludes.

\section{Background}

\subsection{Religion in Rural China}

The Chinese government officially recognizes five religions, which were initially sanctioned in the 1950s, but then abolished during the Cultural Revolution: Buddhism, Daoism, Islam, Catholicism and Protestantism (e.g. Cohen, 1992). The official statistics for religious populations in 2003

\footnotetext{
${ }^{7}$ See also Glennerster et al. (2010) and Dayton-Johnson (2000) for analyses of this relationship in Sierra Leone and Mexico, and Habyarimana et al. (2007) for an experimental study in Uganda. Our study is loosely related to cross-country studies of the relationship between ethnic/linguistic/religious fragmentation and macro economic performance that was pioneered by Easterly and Levine (1997). See also Desmet et al. (2009) and Alesina et al. (2003).

${ }^{8}$ See for instance the recent release of the first Spatial Explorer of Religion (accessible at http://chinadataonline.org/religionexplorer/) a joint initiative of Purdue University and University of Michigan.
} 
are shown in Table 1 column (1). ${ }^{9}$ The most popular official religion is Buddhism, which was introduced from India during the 4th Century. In 2003, 100 million Chinese were officially Buddhists. 90.5 million were of the Mahayana school, which includes distinctly Chinese Han branches of this religion. 7.6 million were Tibetan Buddhists, who mostly live in the province of Tibet. 1.5 million were Theravada Buddhists, who mostly live in the province of Yunnan. The second most popular religion is Islam, which was introduced through the area now known as Xinjiang during the 8th Century. In 2003, approximately 20.3 million of the Chinese population were Muslim. These are followed by the Christian religions, which were introduced in China during the 17th Century. In 2003, Protestantism officially comprised approximately sixteen million followers and Catholicism comprised approximately five million followers. The fifth most popular religion is Daoism, which originated at the same time as Buddhism and is indigenous to China. Approximately three million Chinese were Daoists in 2003.

More popular than all of the official religions combined is what anthropologists and historians refer to as folk religion (e.g., Cohen, 1992). While it is not recorded in official statistics, survey evidence suggests that approximately $20 \%$ of the rural population follows the practices of traditional folk religions (Le and Jiang, 1998: p. 75). Folk religions come in varied and diffused forms, including utilitarian ancestor or lineage worship (worshipping one's ancestors so that the ancestor's soul can intervene on behalf of its living descendants), the worship of local deities, divination, geomancy (e.g. fengshui), witchcraft (e.g., sorcery, exorcism and planchette writing), physiognomy, and certain taboos (Gao, 1994, p.330-55; MacInnis, 1989, p. 367-74, p. 385-410; Dean, 1993; Siu, 1989, p. 121-37). Folk religions tend to vary across regions, and their followers generally believe in several variants at any one time. Since our study focuses on cross-village variation, it is important to note that folk religions typically vary little within each village (Faure and Siu, 1995; Feuchtwang, 2001).

The post-Mao regime (1978- ) has been much more tolerant towards religion than its predecessor (1949-78), which peaked with anti-religion fervor during the Cultural Revolution (1966-76). The policy of the post-Mao regime is similar to the historical policy of the former Imperial governments - although it espouses and promotes one official belief (atheism), it tolerates other religions as long as they do not challenge the power of the central government. During the reform era, all forms of

\footnotetext{
${ }^{9}$ These official statistics are taken from Gong (1998: Table 2).
} 
traditional practices have gradually revived. ${ }^{10}$

Official religions enjoy relatively well-demarcated and open places of worship (e.g., Lai, 2003). Unofficial religions comprise sects of Buddhism/Daoism (e.g., Falung Gong, Zhong Gong Fawen) and Christianity not recognized by the state and Tibetan Buddhists and Xinjiang Muslims who challenge Beijing's control (e.g. Cohen, 1992, Youngliang, 1994). However, these groups are unlikely to be relevant for our context since our sample does not include Tibet and Uyghur regions of Xinjiang, or urban areas, where most unrecognized sects of Buddhism and Protestantism reside. Another group that have had conflict with the central government in the past is the underground Catholic church, which includes individuals (often residing in the rural areas) who follow the Vatican's appointed bishops instead of those appointed by the Chinese State (e.g., Madsen and Fan, 2009; Hunter and Chan, 2007, p. 241; Gong and Zhou, 1999, p. 73). However, the conflict between this group and the state has typically been diplomatic and recent events suggest that a reconciliation has been gradually achieved. ${ }^{11}$ Thus, we believe that it is unlikely for religious-state conflict to play an important role in the context of our study.

There are several additional facts to keep in mind for our analysis. First, religious beliefs in rural China are typically uncorrelated with educational background or occupation (Lai, 2003). In fact, even village officials and Communist Party members are known to partake in religious ceremonies and rituals (e.g., Tsai, 2002, 2007). In a survey of Hubei province, Gong and Zhou (1999, p.71) find that $11 \%$ of the followers of Buddhism and Daoism were school teachers and Party cadres. Second, there is generally little hostility between religious groups in China. For example, anthropologists such as Sweeten (2001) have noted that even before the Communist regime subdued religion, conflict between followers of different religions in rural areas dominated by the Han-Chinese (who are over

\footnotetext{
${ }^{10}$ The revival of religion and state tolerance is consistent with the growth in the number of religious individuals over time. Folk religions were the first to rebound, resulting in a marked rise in the number of new temples being built and a boom in sales of manuals and books on folk religions. Also, survey evidence in Hubei province by Gong and Zhou (1999) show that the number of Buddhists and Daoists fell from 98,000 and 65,300 in 1966 to 93,000 and 46,000 in 1982 , but then grew to be 800,000 and 300,000 in 1996. The number of places for worship and religious meetings in China exhibit the same pattern. They decreased from 120,000 during the early Communist era to 40,000 in the late 1980s, but then grew steadily to 100,000 by 2003 (Zhu, 1994; He, 1999). Similarly, the China Christian Council was re-established in 1980 to repair state-religious relationships with Chinese Christians. According to this organization's statistics, the number of churches grew from 4,000 in 1986 to 7,000 in 1991. Even more numerous were "gathering places", which grew from 25,000 in 1991 to over 50,000 in 2004, 70\% of which are in rural areas (Luo, 2004, Ch. 2).

${ }^{11}$ For example, the recent government appointment of the Bishop of Shanghai, one of the most prominent positions for Chinese Catholics, was neither officially sanctioned nor opposed by the Vatican and followed by members of both the official and under-ground Church (Madsen and Fan, 2009).
} 
$92 \%$ of the total population today) were mostly about practical issues. This is consistent with our belief that religion is a reasonable proxy for social fragmentation and can affect local public goods provision.

Finally, while the revival of religion reflects the persistence of traditional beliefs, the State's past efforts to eliminate religion is believed to have significantly weakened religious beliefs relative their historical predecessors (e.g. Madsen, 1989; Siu, 1989). This implies that the differences between religious groups are likely to be much weaker in China than in other contexts.

\subsection{Village Government and Public Goods}

Villages are the lowest level of administration in rural China. Village governments were first organized by the communist government during the early 1950s and they comprise two groups of leaders: the village comittee and party branch. The village committee, which typically comprises three to five members, is led by the village chairman, henceforth VC. This position is also sometimes called the village chief or village head. The village Chinese Communist Party (CCP) branch, which is similar in size, is led by the party secretary, henceforth PS. Before elections were introduced, all positions were filled by appointment by the county government and village party branch. ${ }^{12}$ Since all levels of government above the village are dominated by the CCP, we will sometimes use the term party to refer to the village party branch and all the upper-levels of government as one body.

The village government serves several critical roles; one that greatly impacts citizen welfare is its power to determine and finance village public goods (e.g., O'Brien, 1994; Oi and Rozelle, 2000; Rozelle, 1994, Brandt and Turner, 2007; Whiting, 1996). The village government allocates public goods spending and raises most of the funds. Since it is not an official level of government, it does not have the legal power to force villagers to comply with local taxation. Instead, village governments finance public goods by imposing ad hoc fees and levies, which they mostly enforce with social pressure and the threat of social sanctions. In our paper, we refer to these tariffs as taxes for simplicity. ${ }^{13}$ The reliance on social mechanisms to enforce tax compliance means that

\footnotetext{
${ }^{12}$ The Chinese government, led by the Chinese Communist Party (CCP), is broadly ordered in a vertical hierarchy, from the central government in Beijing down to the rural levels that comprise counties and townships. According to the National Statistical Yearbooks, rural population decreased from approximately $83 \%$ of total population in 1980 to approximately $75 \%$ by 2000 .

${ }^{13}$ Such taxes can be controversial when villagers believe them to be extortionary and misallocated by corrupt village governments. This led the central government to ban village taxes altogether in the Tax and Fee Reform in 2003. For our study, this ban will have little effect as it occurred towards the end of our study period. But we will check that our estimates are robust to controlling for their introduction. Note that informal taxes have been found to be
} 
raising revenues and determining the object of investment requires a high amount of effort from village leaders. It is therefore not surprising that the provision of public goods prior to the electoral reforms, when leaders had little incentive to exert effort towards satisfying villagers, was far below the demands of villagers (e.g., Luo et al., 2007, 2010).

\section{$2.3 \quad$ Village Elections}

The main motivation for the introduction of elections was to resolve information problems faced by the central government. China is a large, heterogeneous and quickly changing nation with almost 700,000 villages. Proponents of the reform argued that making local leaders accountable to villagers would impose checks on the VC's behavior and would also allow villagers to select the most competent candidates (Kelliher, 1997; O’Brien and Li, 1999). Public goods provision featured prominently in the discussion of whether elections should be introduced, and proponents hoped that local leaders with a democratic mandate would better determine which public good investments were necessary and would better facilitate the local coordination necessary for providing them.

The democratization reforms were gradual. The VC and the village committee were to be elected by the villagers instead of appointed by the regional party and VCs would serve three-year terms with no stipulated term limits. However, to ensure that village leaders would still be partially accountable to the party, there was no change in the selection method of the members of the village party branch and PS positions, who continued to be appointed. Initially, the regional party nominated the candidates but was required by law to nominate more candidates than open positions. Only in a second wave of reforms were nominations opened to all villagers. This is commonly referred to as haixuan. Both reforms were irreversible - once elections or open nominations were introduced, they remained in place thereafter.

Elections were introduced in a top-down fashion by the provincial and county governments as early as the late 1970s and early 1980s. Once the provincial government decided to implement village elections, almost all villages within that province followed shortly thereafter (O'Brien and Li, 1999). By all accounts, villages had little discretion over the timing of introduction of elections, which is characteristic of reforms in rural China. ${ }^{14}$ Our companion paper uses the same data that we use

important in other contexts such as in Indonesia (e.g. Singhal and Olken, 2009).

14"These [elections] should not be interpreted as bottom-up initiatives by the villagers themselves; they are not in a position to play any precedent-setting part in the initiation of new electoral reforms. There is a mistaken belief among some people outside China regarding this... elections are quietly being instituted at levels above the village, 
here to document that the roll-out of elections was consistent with rapid top-down implementation. Most villages within a county implemented elections in the same year, and over $60 \%$ of villages within a given province introduced elections within three years of the first election in that province (Martinez-Bravo et al., 2012).

After some debate within the party, village elections were formally codified by the central government in the Organizational Law on Village Committees (henceforth OLVC) in 1987. From this point onwards, all provinces were pushed to introduce elections for all rural areas. A later revision of the OLVC in 1998 required candidate nominations to be open to all villagers.

\section{Conceptual Framework}

\subsection{Religious Fragmentation, Public Goods Provision and Elections}

Social Heterogeneity and Public Goods The first step towards conceptualizing the relationship between religious diversity, government-provided public goods and elections is to focus on the different mechanisms that link social heterogeneity and low public goods, regardless of institutions. Existing research has proposed several different channels to explain the often observed negative cross-sectional correlation between fragmentation and public goods provision. This literature, reviewed in Alesina and Ferrara (2005) and Banerjee et al. (2008), often considers a public goods game in which citizens willingly contribute to the public good. In the case of rural China, the village government needs to collect contributions to provide goods, but has limited enforcement power. Hence, the insights of the literature are applicable to this context - i.e., by refusing to cooperate, villagers have the ability to significantly increase the cost of collecting contributions for the village government. These increased costs will decrease the provision of public goods through a mechanism similar to the voluntary contribution public goods game.

Among the proposed mechanisms, the most plausible in the context of rural China is that religious activity induces altruism, trust, and willingness to join efforts with other members of the religious group (Vigdor, 2004; Guiso et al.; Alesina and Ferrara,2000). Rituals, practices and festivals throughout the year induce repeated and intense interactions among those who share their faith, facilitating communication, trust and empathy. As in many other contexts, each religious group builds a strong social identity that helps accumulate these different dimensions of within-group

engineered first in selected districts at a distance from Beijing, through the connivance of the [central] Ministry of Civil Affairs and middle-ranking officials out in the regions." - Unger (2002, p. 222). 
social capital. Theoretically, in the extreme case in which religious participants fully internalize the preferences of the other followers of their faith, a religiously homogeneous village would enjoy optimal voluntary contributions to the public good. By the same logic, to the extent that altruism and trust are limited to the religious group, the more fragmented the village, the lower the willingness to contribute to public goods. ${ }^{15}$ Similarly, social sanctions might be weaker for members of other religious groups, which results in less social leverage for enforcing contributions in fragmented villages (Miguel and Gugerty, 2005). Note that this mechanism would be active even if there was consensus on which public good to provide and what would be the ideal level of expenditure.

A different mechanism posits that preferences differ across groups. In particular, groups might prefer different varieties of public goods, and technological constraints are such that only one variety can be provided (Alesina et al., 1999). In a fragmented village, villagers might refrain from contributing since they suspect they will not get their preferred variety. In the context of rural China this mechanism would be most directly relevant when the public good under consideration is schooling, since different religions might have diverging preferences over the religious orientation of education. However, note that even if all citizens prefer the same public good, such as better irrigation, groups can still differ on their preferences over the location of the public amenity since individuals of similar religions often cluster into neighborhoods within villages (e.g., Cohen, 1992). Hence religious diversity may also result in preference divergence for public goods due to the geographic differences across groups. ${ }^{16}$

In the extreme, divergent preferences can generate wasteful conflict between groups (Esteban and Ray, 1999; Montalvo and Reynal-Querol, 2003). Such conflict could also result in lower public good provision. However, given the scant anecdotal evidence of conflict across religious affiliations in China today, this does not appear to be a first order mechanism for our context.

\section{The Interaction of Social Heterogeneity and Elections in Determining Public Goods}

The mechanisms discussed so far predict a negative cross-sectional relationship between fragmentation and public goods provision given a fixed institutional environment. Hence, we would expect the

\footnotetext{
${ }^{15}$ For example, Guiso et al. (2003) finds that religious people are more intolerant of diversity than non-religious ones, regardless of the type of religion, albeit some religions are worse than others.

${ }^{16}$ This has been documented in historically in mainland China (e.g., Yang, 1961, p. 98, 158) and in a modern context in Taiwan (e.g., Deglopper, 1974, p. 65). Unfortunately, our data does not allow us to identify the geographic location of households within villages.
} 
level of public goods to be higher in homogeneous villages under both appointed leaders (e.g., our baseline before the electoral reforms) and under elections (e.g., after the electoral reforms). However, there are two main differences between the two institutional situations: (i) elections increase accountability to villagers and (ii) elections provide a mechanism for preference aggregation. As we now discuss, these two functions of elections have opposite predictions on the sign of the interaction effect of fragmentation and the introduction of elections.

On the one hand, elected leaders are more directly accountable to citizens than appointed leaders. This has two effects reinforcing effects. First, accountable governments better reflect the preferences of the population. As discussed above, fragmented villages have a lower preference for public goods, so the relationship between heterogeneity and public goods provision should be stronger - more negative - under elected leaders than under appointed leaders, since the former are more responsive to the underlying preferences of the village than the latter. Second, all else equal, citizens are more willing to contribute to the village government for public goods when they feel that they can hold the government accountable. A necessary condition for effective government accountability under elections is that some citizens need to gather and distribute information on government performance. Since these monitoring activities are public goods in themselves, and public goods are better provided in homogeneous villages for the reasons stated earlier, elected officials are more accountable in homogeneous villages. ${ }^{17}$ This causes villagers to be more willing to contribute to the government for public goods when the government is elected rather than appointed, and more so in homogeneous villages. These two mechanisms predict that the interaction effect of elections and heterogeneity is negative.

On the other hand, elections also serve as a mechanism for aggregating voter preferences. In fragmented villages, with low communication and contentious relationships across groups, it is likely to be more difficult for appointed village leaders to determine the most preferred public goods by the majority of villagers. His inability to propose the majority-preferred public good will cause villagers to resist contributing to the public goods that he chooses. Hence, in terms of preference aggregation, heterogeneous villages will have more to gain from the introduction of elections. This mechanism predicts that the interaction effect of elections and heterogeneity is positive. This mechanism is

\footnotetext{
${ }^{17}$ For a review of reasons why democracy works better in high social capital environments see Boix and Posner (1998). See also Banerjee and Pande (2007), Bandiera and Levy (2010) and PadroiMiquel (2007) for other reasons strongly fragmented polities find it difficult to keep elected leaders accountable.
} 
likely to be stronger if the pre-election correlation between heterogeneity and public goods is highly negative, since it is predicated on heterogeneous villages catching up to homogeneous villages.

As we show below, in the context of rural China, prior to the implementation of elections public goods provision was extremely low and not correlated to fragmentation. This is most probably a result of lack of accountability: since the village leaders were appointed by upper levels of government, they could i) safely ignore the preferences of the villagers and ii) shirk the work necessary to accomplish public goods provision. This fact has two consequences.

First, the theoretical discussion above suggests that the interaction between elections and heterogeneity will be negative. Since the relationship between heterogeneity and public goods is nonexistent before elections, there is very little catching up that heterogeneous villages can do. As a consequence, the accountability mechanisms described above should dominate. Hence, we will interpret a negative interaction as the result of the fact that the accountability introduced by elections works better in homogeneous villages. As described, this is reinforced by the fact that in heterogeneous villages, preferences are such that public goods games result in lower provision, and the newly introduced accountability also induces the elected government to closely reflect this.

Second, because there is no relationship between heterogeneity and public goods under the appointment regime, our empirical analysis will not be able to clearly distinguish between the different mechanisms that the literature proposes for the cross-sectional relationship between heterogeneity and public goods. In other words, our estimates will capture the sum of these mechanisms.

\subsection{Religious Fractionalization}

We measure fragmentation with an index of fractionalization, which proxies for the lack of trust and altruism and the difference in preferences regarding the type of public goods across groups (e.g., Alesina et al. (2003), 2003). This can be written as

$$
F_{i}=1-\sum_{j=1}^{N} s_{i j}^{2} .
$$

The fractionalization index for village $i$ is equal to one minus the sum of the squares of $s_{r i}$, the population share of religion $j$ in village $i$, where $N$ is the total number of religions. This index captures the probability that two randomly drawn villagers belong to different groups.

Note that an alternative index used to measure heterogeneity is the polarization index (e.g., Montalvo and Reynal-Querol, 2003; Esteban and Ray, 1994). In principle, this index captures the 
potential for conflict for a given group composition. However, in our context, the fractionalization and polarization indices are highly positively correlated (and there is little known conflict across religious groups). ${ }^{18}$ Hence, in our context the two indices are conceptually similar and we focus on the fractionalization index for brevity. Nonetheless, when we present the baseline estimates, we will show that our results are similar when we use the polarization index.

\subsection{Identification}

The main outcome we examine is village government expenditure on public goods. To estimate the impact of voter heterogeneity on expenditures induced by the introduction of elections, we estimate the following equation

$$
Y_{i j t}=\alpha_{1} E_{i j t}+\alpha_{2}\left(E_{i j t} \times H_{i j}\right)+\beta_{1} O_{i j t} \times+\beta_{2}\left(O_{i j t} \times H_{i j}\right)+\gamma X_{i j t}+\tau \theta_{j}+\delta_{i j}+\rho_{t}+\varepsilon_{i t},
$$

where the outcome of interest for village $i$ in province $j$ during year $t$ is a function of: the interaction effect of fragmentation, $H_{i j}$, and the introduction of elections, $E_{i j t}$; the interaction term of fragmentation and the introduction of open nominations in each village, $O_{i j t}$; the main effects of the introduction of elections and open nominations; a vector of village-year specific controls, $X_{i j t}$; province-year trends, $\tau \theta_{j}$; village fixed effects, $\delta_{i}$; and year fixed effects, $\rho_{t}$.

Our main estimates cluster the standard errors at the village level to correct for serially correlated shocks within each village. Given the top-down nature of the reform, one may also be concerned about correlated shocks within provinces. To address this, we will also present the standard errors clustered at the province level and show that they are very similar.

In this equation, village fixed effects control for all differences across villages that are timeinvariant (e.g., geography, the main effect of fragmentation), and year fixed effects control for all changes over time that affect villages similarly (e.g., macro economic growth, economic liberalization). Moreover, province-time trends control for the regional economic and cultural divergence across China during our period of study (e.g. the coastal regions experienced more rapid economic growth and were more exposed to outside cultural influences). ${ }^{19}$ Because elections were introduced

\footnotetext{
${ }^{18}$ The polarization index is

$$
P_{i}=1-\sum_{j=1}^{N}\left(\frac{0.5-s_{i j}}{0.5}\right)^{2} s_{i j} .
$$

The correlation is 0.98 across villages and statistically significant at the $1 \%$ level, see Appendix Figure A.1.

${ }^{19}$ We can alternatively control for distance to the coast interacted with year fixed effects, province GDP, province GDP growth or other province-level time-varying controls. The estimates are very similar and we do not present these alternative results for brevity. They are available upon request.
} 
rapidly across villages within provinces, we do not have enough variation in the data to control for province-year fixed effects. However, after we present the main results, we will show that our results are robust to controlling for province-time trends with other functional forms.

The vector of controls, $X_{i j t}$, includes several variables. First, we control for village population, which addresses the fact that there may be economies of scale in public goods provision or that it may be more difficult to coordinate larger populations. Second, we control for the share of village population that is religious, which is highly correlated with religious heterogeneity and could affect the provision public goods. Since we use it as a time invariant measure, we control for its interaction with the full set of year dummy variables to allow its influence to vary flexibly over time. Finally, we control for the interaction of religious heterogeneity and year fixed effects. Since our heterogeneity measure is time invariant at the village-level, we interact it with the full set of year fixed effects to allow villages to differ according to the level of fragmentation in a way that is fully flexible over time. Hence, our estimate of the interaction of heterogeneity and the introduction of elections is very conservative in that it captures the systematic change in public goods after the introduction of elections in villages with higher levels of heterogeneity that is not already captured by the interactions of heterogeneity and year fixed effects.

To interpret the estimates, consider the case of religious fragmentation. $\alpha_{1}$ is the total effect of the introduction of elections for villages with no fragmentation, $H_{i}=0 . \alpha_{1}+\alpha_{2}$ is the total effect of the introduction of elections for villages where there is a high ("infinite") degree of fragmentation, $H_{i}=1 . \alpha_{2}$ is the differential effect of the introduction of elections between these two types of village. The hypothesis that religious fragmentation limits the benefits of the introduction of elections predicts that $\hat{\alpha}_{2}<0$. In contrast, if fragmentation has no influence, then $\hat{\alpha}_{2} \approx 0$.

Conceptually, our empirical strategy is similar to a triple differences estimate (DDD). We compare public goods investment: $i$ ) in villages before and after the introduction of elections (first difference), ii) between villages that have already introduced elections to those that have not (second difference), and iii) between villages that have high heterogeneity to villages with low heterogeneity (triple difference). Our identification strategy makes two assumptions. First, we assume that our measure of religious fragmentation is not affected by the introduction of elections. We will demonstrate that this is true with the data before we present the main results. Second, we assume that conditional on the baseline controls, our measure of heterogeneity is not correlated with other 
factors that influence the effects of elections on public goods expenditures. We do not take this as given and will provide a large body of evidence to address this concern after our main results. It is important to note that our differences strategy does not rely on the timing of the introduction of elections being random.

\section{Data}

\subsection{Main Data Sources}

This study mainly uses village- and year-level data from a panel of 217 villages for the years 1986-2005 from The Village Democracy Survey (VDS), a unique retrospective survey conducted by the authors of this paper. In 2006, our survey recorded the history of electoral reforms and public goods expenditures. In 2011, we returned to the same villages to collect data on the presence of voluntary social organizations and on the number of households per surname for the four most prevalent surnames in the village roster (in 2011), which we will use in the robustness exercises. ${ }^{20}$ Our main variables are obtained from village records, and therefore are not subject to reporting or recall biases. For information not contained in records, our survey relies on the collective response of current and former living village leaders and elders, who were all invited to be present together to answer our surveyors. The only variables in this study that rely on these responses are those related to family trees, which are used in the robustness exercises.

We supplement the VDS with annual data collected each year by the Ministry of Agriculture in the National Fixed Point Survey (NFS), which surveys the same villages as the VDS. These surveys are nationally representative and the villages are updated over time. The NFS began in 1986 and is available for each year, except 1992 and 1994 for administrative reasons. The NFS provides us with data on village household income, inequality, the share of population that is religious and many other demographic variables.

These two surveys are merged at the village and year level to form the sample that we use for estimating the main results. It comprises a balanced panel of 217 villages for the years 1986-2005. In addition, the NFS surveys a random sample of approximately 100 households per village each year (out of approximately 420 households per village on average) with detailed questions regarding

\footnotetext{
${ }^{20}$ For administrative reasons, the 2011 wave includes only 195 of the original villages. The VDS questionnaires are available at

http://www.econ.yale.edu/ nq3/NANCYS_Yale_Website/Village_Democracy_Survey.html
} 
household expenditures. We were able to obtain this additional household data for approximately a third of the villages in the total sample.

These are the most comprehensive data on village-level reforms and village-level outcomes ever constructed, as well as the first data to document religious composition of rural villages in post-Mao China. Our data cover a larger and more nationally representative sample, and span a longer time horizon than any other existing data of rural China that are available to researchers. The panel aspect of our data means that we can control for village fixed effects and year fixed effects. Since we have many villages from each province, we can also control for province-year trends, which are important for addressing the growing economic divergence across regions in China. An additional advantage of the data is the accuracy and uniformity of the historical public expenditures data, which come from administrative records overseen by the Ministry of Agriculture. The Ministry of Agriculture imposes the same book keeping rules across villages and requires each village to record public goods expenditure by type and by the source of financing. The latter adds to the granularity and comparability of the data. Note that government policy strictly limits permanent migration from rural areas. ${ }^{21}$

\subsection{Measuring Religion}

The NFS categorizes religions according to the official religions that are sanctioned by the State: Buddhists, Christians, Muslims and "other" religions, which in our context mostly comprise of Daoists. We categorize the remaining villagers as "atheists." Hence, for the fractionalization index shown in equation (1), $N=5$. The data on the share of population belonging to each religion is collected by the NFS for the years 1993 and 1994-2002. These data are obtained by asking village leaders for the number of individuals that belong to each official religion. To minimize misreporting, surveyors only ask about officially sanctioned religions and ask village leaders instead of individual villagers, who may have outdated perceptions of government attitudes towards religion. The authors of this paper conducted numerous interviews with village officials, county-government officials and Ministry of Agriculture surveyors. Based on these and the structure of the survey, we have little reason to doubt the integrity of the NFS data on religious composition.

\footnotetext{
${ }^{21}$ Workers in China often migrate temporarily for work. However, the household registration system that ties access to public goods and government benefits makes permanent migration costly. Also, rural residents are also dis-incentivized to migrate permanently away because that results in the loss of the right to farmland.
} 
The main caveat for our measure is that our data only includes official religions. For reasons that we discussed earlier, this categorization causes the substantial group of villagers that practice folk religions to be mis-measured as "atheists". Another concern is that Protestants and Catholics are mixed into one group of "Christians". We will address these issues and other concerns of mismeasurement by constructing alternative measures of religion with independent data collected by academics. Since the results using imputed measures are similar to those using the NFS data, we will use the NFS data as our main measure and present the alternative results afterwards in the Robustness section.

The religion data varies over time in the number of followers of each religion within as well as across villages. ${ }^{22}$ The population that belongs to each religion increases over time, which is consistent with the national trends. This is consistent with the data capturing real information. To maximize the number of observations for our estimates, we average the share of population belonging to each religion in each village over time. Thus, the measures of the share of religious population and religious fractionalization we use for the analysis will be time-invariant.

\subsection{Descriptive Statistics}

The average village has 420 households. By the end of our sample, all villages had introduced elections, but only half of them had introduced open nominations. Indeed, $50 \%$ of villages introduced elections between 1984 and 1993. Public goods expenditures by the village government follow Ministry of Agriculture guidelines. In descending order of the average share of total public expenditures, the categories are roads and sanitation, irrigation, electricity, schools, planting trees and the environment, and other. $68 \%$ of all government spending on public goods is financed with funds raised from villagers, while the rest is funded by transfers from higher levels of government. ${ }^{23}$

Regarding religious composition, the descriptive statistics are presented in Table 1 columns (4)(6). The average level of fractionalization, which we calculate from the data on the population shares of each religion and non-religious individuals, is 0.053. Crucially for our paper, the standard deviation of 0.1 shows that there is significant variation across villages despite the fact that average

\footnotetext{
${ }^{22}$ The mean religious fractionalization across villages is .053, whereas the average standard deviation of this variable over time within-village is .0355 .

${ }^{23}$ For a more comprehensive discussion of the VDS data, see a companion study on the effect of the introduction of elections on economic policy by Martinez-Bravo et al. (2012). The main economic and demographic variables for our analysis and the data source are shown in Appendix Table A.1.
} 
fractionalization is low. Figure 1a presents a histogram of the fractionalization index across villages. It shows that while approximately $40 \%$ of villages have zero fractionalization, there is substantial variation across the remaining $60 \%$ of villages. To better illustrate this variation, Figures $1 \mathrm{~b}, 1 \mathrm{c}$ and $1 \mathrm{~d}$ present similar histograms for the villages in the bottom half, top half and top quarter of the distribution of religious fractionalization. They show that there is significant variation in fractionalization across villages, especially for high levels of fractionalization.

Another important fact to note is that there is substantial variation in religious fractionalization both across and within provinces. This can be demonstrated by regressing average fractionalization on province fixed effects. The R-Squared is 0.51 . In other words, $49 \%$ of the variation in fractionalization is within provinces. ${ }^{24}$

There are still several potential concerns over our using a measure of average religious composition for our main empirical analysis. First, one may be concerned that the timing of the elections is correlated with religious fractionalization, which raises the issue of omitted variables for our interpretation - i.e., religious fractionalization is correlated with other factors that influence elections and public goods. Second, even if we establish that the electoral reform timing is uncorrelated with religious fractionalization, one may still be concerned that the introduction of elections affected the religious composition of villagers. It is possible that our explanatory variable, which is the average of religious composition from pre- and post-reform years, confounds aspects of religious composition that are uncorrelated to elections with aspects that is are potential outcomes of elections. In the next two sections of the paper, we will mitigate these concerns by showing that neither relationship exist in the data.

\subsection{The Correlates of Religious Fractionalization}

Table 2 aggregates our data to the village level and presents the correlates of religious fractionalization. It also shows that fractionalization is positively correlated with total village population, (mechanically) correlated with the population share of all religious individuals, and positively correlated with the pre-election level of income. These correlations highlight the fact that fractionalization is not randomly assigned and the need to carefully control for the correlates of fractionalization in our empirical analysis.

\footnotetext{
${ }^{24}$ These estimates are not presented in tables for brevity.
} 
Note, however, that fractionalization is not correlated with pre-election income inequality. Nor is it correlated with the fraction of high school graduates in a village. Interestingly, fractionalization is uncorrelated with the physical geography of a village, which we measure with three dummy variables that reflect whether a village is in a plain, hilly or mountainous region (these are official definitions provided by the Ministry of Agriculture). This is likely due to the fact that villagers typically live in one geographic cluster so that the terrain for the village at large does not affect the fragmentation of households. Similarly, there is no correlation between religious fractionalization and the fractionalization of surnames. The latter captures the presence of different kinship groups, which could be another dimension of social clustering. We do find that religious fractionalization is positively correlated with the presence of a village temple and the number of Buddhist temples in the same county in $1820 .{ }^{25}$ We will return to discuss these variables after we present the main results.

Finally, there are two pieces of information that are important for our approach. First, note that fractionalization is uncorrelated with the average pre-election level of government spending on public goods, and the fraction that is financed by villagers. This is consistent with the belief that there was little difference in government public goods provision across villages prior to elections because provision was universally low, and that any existing differences were unrelated to social heterogeneity. Second, fractionalization is uncorrelated with the timing in the introduction of elections (or open nominations), which supports the belief that fractionalization did not affect the way elections were rolled out.

It is important to emphasize that the correlation between average fractionalization and other variables does not confound our baseline estimates per se, because the baseline controls of the interaction of average fractionalization and year fixed effects control for all differences between fragmented and less fragmented villages in a way that is fully flexible over time. In the section on robustness, we will demonstrate the robustness of our baseline estimates by controlling for the interaction of these correlates (and other variables) with the introduction of elections.

\footnotetext{
${ }^{25}$ The latter variable is obtained from Qing Dynasty Gazetteers (1820).
} 


\section{Results}

\subsection{Main Results}

To allay concerns that our measure of average fractionalization is endogenous, we first establish that the introduction of elections has no effect on a time-varying measure of religious fractionalization. To support this claim, we regress the time-varying measure of fractionalization on the introduction of elections. ${ }^{26}$ The sample for this regression is smaller than the full sample because it is restricted to villages that held its first election after 1993, when the NFS begin to collect religious population data. The post-election dummy in Table 3 column (1) shows that there is no effect; the coefficient is small in magnitude and statistically insignificant. Together with the descriptive statistics which show that average fractionalization and election timing is uncorrelated, we conclude that there is no relationship between religious fractionalization and elections per se. Henceforth, we only consider the time-invariant measure of average religious fractionalization since this allows us to extend the empirical analysis to the mid 1980s.

For the rest of the table, the dependent variable is government public goods expenditure, measured in 10,000s RMB. In column (2) we estimate a similar equation to equation (3), except that we replace the village fixed effects with the religious fractionalization main effect to examine the preelection difference in public goods expenditure across villages of different levels of fractionalization. The estimate of the main fractionalization effect is small in magnitude and statistically insignificant. This, together with the qualitative evidence and the correlations shown earlier, establishes that fragmented and homogeneous villages had very similar public goods expenditure prior to the first election.

Column (3) presents our baseline estimate. The main effect of elections is positive and the interaction effect with religious fractionalization is negative. Both are statistically significant at the $1 \%$ level. To assess the magnitude of the coefficients, note that the estimates for the main effect of post-election in column (3) shows that the introduction of elections increased government public goods expenditure by 207,300 RMB (37,914 Constant 2000 USD) for villages with zero

\footnotetext{
${ }^{26}$ We estimate the following equation

$$
H_{i j t}=\alpha E_{i j t}+\beta O_{i j t}+\gamma X_{i j t}+\tau \theta_{j}+\delta_{i}+\rho_{t}+\varepsilon_{i t}
$$

where religious fractionalization for village $i$ in province $j$ during year $t$ is a function of: the introduction of elections, $E_{i j t}$; the introduction of open nominations in each village, $O_{i j t}$; village population, $X_{i j t}$; province-year trends, $\tau \theta_{j}$; village fixed effects, $\delta_{i}$; and year fixed effects, $\rho_{t}$.
} 
fractionalization. For villages with the mean level of fractionalization of 0.053 , elections increased government public goods expenditure by 150,040 RMB (21,194 Constant 2000 USD, $(-107 \times 0.053+$ $20.73) \times 10,000=150,040)$. This is shown at the bottom of the table in column (3).

Another way to assess the magnitude is to ask how many villages experienced increases in public goods due to the introduction of elections given their levels of religious fractionalization. Dividing the absolute values of the main effect by the interaction effect $(20.73 / 107)$, we find that a village with a fractionalization index below 0.193 will experience some increase in public goods from the introduction of elections. This includes approximately $92 \%$ of the villages in our sample. Thus, our results show that although increased religious fractionalization reduces the increase in government public goods expenditure that followed the introduction of elections, most villages were homogenous enough to experience some increase.

In terms of standard deviations, we find that a one standard deviation increase in fractionalization (0.105) causes the increase in public goods expenditure due to elections to decline by 112,560 $\operatorname{RMB}(0.105 \times-107=11.255)$, which is 0.08 standard deviations of average public goods expenditure $(11.255 / 135.466=0.083)$. Thus, our estimates imply strong, but plausibly sized effects of heterogeneity.

In column (4), we examine polarization while controlling for all of the baseline coefficients. The estimated interaction effect is negative and statistically significant at the $1 \%$ level, and the magnitude is about half of that of fractionalization in column (1). Since the standard deviation of polarization doubles that of fractionalization, the implied effects for heterogeneity are essentially the same, which is not surprising since these two variables are highly correlated in the data.

We do not control for fractionalization and polarization simultaneously due to their high correlation. Hence, our results cannot distinguish the role of cross-group conflict from the other mechanisms discussed in Section 3. However, the lack of documented open conflict between religious groups in the provinces of our study suggests that the most plausible mechanism behind the deleterious effect of heterogeneity on elections is given by the interaction of the lack of trust, empathy and divergent preferences with the increase in accountability brought about by the reform.

In column (5), we address the concern that the top-down nature of electoral reforms means that correlated shocks within provinces may cause our main estimates to under-reject hypotheses. We therefore alternatively estimate the baseline equation by clustering the standard errors at the 
province level. The standard errors are very similar to those clustered at the village-level. However, one may be concerned that having 29 provinces can induce small-sample bias when we cluster at the province level, so we address this by correcting for potential biases with wild-bootstrapped standard errors as recommended by Cameron et al. (2008). The standard errors, presented in column (6) are almost identical. Since the different levels of clustering make little difference to our estimates, we will continue to present standard errors clustered at the village-level.

Finally, we note that the estimated effect of the introduction of open nominations and religious fractionalization is always small in magnitude and statistically insignificant, as is the main effect of open nominations. For this reason we will not report these coefficients in the rest of the regressions. ${ }^{27}$ We return to discuss the estimate in column (7) later in the paper.

\subsection{Timing of the Effects}

In order to ensure that the estimated effects are a consequence of the introduction of elections and not of spurious changes that may have occurred in the pre- or post-election periods, it is important to examine the timing of our estimated effects. We estimate the following equation

$$
\begin{aligned}
y_{i t} & =\sum_{\tau=-3}^{4} \alpha_{\tau} e_{i t \tau}+\sum_{\tau=-3}^{4} \beta_{\tau}\left(e_{i t \tau} \times H_{i}\right)+\sum_{\tau=-3}^{4} \theta_{\tau} o_{i t \tau} \times+\sum_{\tau=-3}^{4} \lambda_{\tau}\left(o_{i t \tau} \times H_{i}\right) \\
& +\gamma X_{i j t}+\tau \theta_{j}+\delta_{i j}+\rho_{t}+\varepsilon_{i t},
\end{aligned}
$$

where $e_{i t \tau}=1$ if village $i$ experienced the introduction of elections $\tau$ years ago in year $t$, and $o_{i t \tau}=1$ if village $i$ experienced the introduction of open nominations $\tau$ years ago. The other variables have the same notation as in the baseline equation. ${ }^{28} \alpha_{\tau}$ is a vector of dummy variables that captures the number of years since the first election for villages with zero fractionalization $\left(F_{i}=0\right), \beta_{\tau}$ is a vector of coefficients that reflects the differential effect of elections between hypothesized villages with fractionalization equal to one and villages with with zero fractionalization, for each year since the election. $\theta_{\tau}$ and $\lambda_{\tau}$ are the analogous estimates for the introduction of open nominations.

For our identification strategy, we would like to establish that there are no pre-trends in public goods expenditure in the years leading up to the first election $\left(\hat{\beta}_{\tau} \approx 0\right.$ when $\left.\tau<0\right)$; that for villages with no fractionalization, the positive effect on public goods expenditure occurs with the introduc-

\footnotetext{
${ }^{27}$ They are available upon request.

${ }^{28}$ Note that although we examine a similar window of time before and after each reform for consistency, we do not exclude any observation. Instead, we follow convention to maximize the information in our estimation and group all of the observations that are four or more years prior to the first reform together, and they constitute the reference group; and similarly, we group all of the observations that are four or more years after the reform together.
} 
tion of elections $\left(\hat{\alpha}_{\tau}>0\right.$ when $\left.\tau \geq 0\right)$; and that public goods expenditure between homogenous and heterogeneous villages diverge when elections are introduced $\left(\hat{\beta}_{\tau}<0\right.$ when $\left.\tau \geq 0\right)$.

The estimates are presented in Appendix Table A.2. ${ }^{29}$ The coefficients of the dummy variables for the years since the first election and the coefficients of their interaction with religious fractionalization are plotted in Figure 2a (on two different vertical axes for presentational purposes). It shows that there is no pre-trend in government spending on public goods in the years leading up to the first election for either homogenous or heterogeneous villages. Consistent with the "parallel trends" assumption, the pre-election coefficients move in parallel between the two types of villages. The spending in the two types of villages diverge exactly when elections were introduced - they increased for very homogenous villages and decreased for very heterogenous villages. These estimates provide strong support for our identification strategy and interpretation.

In Figure $2 b$, we plot the effect of elections over time for the average village $\left(\hat{\alpha}_{\tau}+0.053 \hat{\beta}_{\tau}\right)$. This figure shows that the average village experienced no change in public goods expenditure over time prior to the introduction of elections, but then experienced an increase when elections were introduced. The large increase in the first year after elections are introduced may reflect the newly elected government's response to latent demand for public goods. However, the important fact to note is that although spending is somewhat lower in the second and third years after the first election, all post-election spending is nevertheless positive and much higher than pre-election years. ${ }^{30}$

\subsection{Public Goods Provision}

Our main results focus on public goods expenditure mainly because the data for this measure are better than the data on provision. However, we are able to proxy for the provision of two public goods that together approximately constitute a quarter of total public goods expenditure by the village government; we proxy for irrigation with the amount of arable land in a village, and for schooling with primary school enrollment rates. This is based on the logic that increases in spending on irrigation should increase the amount of arable land and increases in spending in schooling should increase enrollment rates. In our sample, $83 \%$ of the villages have a school and

\footnotetext{
${ }^{29}$ Note that the statistical significance of the year-by-year interaction point estimates is not important. Instead, we are interested in the joint statistical difference between the point-estimates after the reform and those before the reform, which is similar to the main interaction effect of the introduction of elections and religious fractionalization.

${ }^{30}$ Our main pre-post estimates are very similar when we exclude the first year after the first election. These estimates are not presented for brevity.
} 
$94 \%$ of these are primary schools (the others are middle schools). These data are not available for all years, which reduces the precision of our estimates. Table 4 columns (2) and (3) show that the estimated interaction effect of religious fractionalization and the introduction of elections on these proxies for provision are negative and the main effects of the introduction of religion are positive, as in the baseline equation, restated in column (1). The interaction effects are statistically significant at the $15 \%$ and $1 \%$ level. These results show that actual public good provision followed the same pattern as recorded expenditure and support our interpretation of changes public goods expenditure as reflecting changes in public goods provision.

Note that an interesting implication of the changes in provision is that the increase in public expenditure is unlikely to have completely crowded-out private expenditure on public goods. If there is complete crowd-out, we should observe no change in provision. ${ }^{31}$ For a third of the sample, we can investigate this more directly by examining private expenditures on irrigation and schooling as outcomes in columns (4) and (6) (columns (5) and (7) repeat the estimates for public goods provision on a similarly restricted sample of villages). Column (4) shows that household expenditures parallel public expenditure for irrigation, but, interestingly, this is not the case for expenditure in schooling, in column (6). For the latter, it seems that there is some substitution of public and private expenditure.

\subsection{Interpreting the Results}

Local Funds for Public Goods The main results show that elections increased public goods expenditure, but that this increase was smaller in fragmented villages. Following the discussion in section 3, we interpret our results as evidence that voter heterogeneity causes elected governments to be unwilling or unable to finance public goods. In Table 5, we examine alternative explanations that might threaten this interpretation.

First, we examine government expenditure on public goods separately according to the source of the funds. A comparison of columns (1) and (2) shows that the main results on total public goods is entirely driven by financing from villagers. In contrast, column (3) shows that there is no effect on funds from the upper government. Consistent with our interpretation, this provides strong evidence that the effect of heterogeneity is local to the village.

\footnotetext{
${ }^{31}$ See Hungerman (2007) and the studies referenced within for empirical evidence on private-expenditure crowd-out in other contexts.
} 
Column (4) examines tax payments made by households to local governments. Unfortunately, this measure includes payments to the county and township as well as to the village governments, and is only available for a third of the villages in our sample. Nevertheless, it is interesting to note that the signs of the main effect and interaction effect are consistent with those in columns (1)-(3). This estimate is insignificant, but it also points in the direction of our interpretation.

We interpret religious fragmentation as a proxy for reduced cross-group social capital caused by social clustering along religious lines. While we cannot test for this directly, we can investigate if there is a difference in terms of the presence of social organizations between homogeneous and heterogeneous villages. The VDS survey measures the presence of organizations that are voluntary, do not exclude any villager, and are partly or wholly funded and organized by villagers. Approximately $14 \%$ of our village-year observations have at least one such organization. Column (5) shows that the interaction effect on voluntary village-wide social organizations is large in magnitude and negative in sign. However, it is not statistically significant. Thus, we interpret this as weak suggestive evidence consistent with heterogeneous villages having reduced village-wide social capital also after the introduction of elections.

Alternative Mechanisms An obvious alternative to our preferred interpretation is that the central government changed public goods targeting when elections were introduced such that it favored homogenous villages. However, our finding that the interaction effect of the introduction of elections and fractionalization on public goods expenditures financed with funds from the upper government is zero makes this alternative highly unlikely.

Another potential threat for our interpretation is that our main results may be driven by poor implementation of the electoral reforms in fragmented villages. For instance, this would be the case if the limited interaction across religions makes it more difficult to inform villagers of proper electoral procedures, and therefore allow more corrupt elections. If this were true, then the correct interpretation of our main results would be that heterogeneous communities underwent less formal institutional change. To investigate this hypothesis, we collected data on the occurrence of the most common aberrations in elections from village records. These include the presence of roving ballot boxes, not having anonymous ballots, and allowing voting by proxy without a signed permission form by the individual who is away. We create a dummy variable that equals one if any of these 
aberrations occurred after the introduction of the first election, or if it is before the first election. In our sample, $85 \%$ of the observations have poor quality elections. We examine this variable as the dependent variable in our main estimating equation. Table 6 column (1) shows that the coefficient of the interaction term between fractionalization and post first election is very small in magnitude and statistically insignificant. Thus, we conclude that our estimates are not driven by differences in electoral quality between heterogeneous and homogenous villages.

Similarly, we can examine other political outcomes that may reflect the quality of elections such as voter participation, the probability that the newly elected VC was persecuted during the Cultural Revolution, was from a family that was officially classified as a rich farmer or landlord in the initial communist land reforms during the early 1950s, or was a party member before entering the office. As a placebo, we can also examine the characteristics of the Party Secretaries (PS), who were not directly affected by elections. These data are recorded by the VDS and vary slightly in the number of observations because records were not always available. The estimates in columns (2)-(8) are all statistically zero. There is no evidence that elections were implemented or interpreted differently across villages of different levels of heterogeneity. Consistent with the anecdotal evidence, there is no effect on the PS.

Finally, note that mean reversion is extremely unlikely to have caused our results, since we find that there is little difference in pre-election public goods expenditure between homogeneous and heterogeneous villages (Table 3 column (2)).

\subsection{Robustness}

Mismeasurement of Religious Composition The NFS data on religious composition does not distinguish between Catholics and Protestants and only report officially sanctioned religions, which will cause individuals who follow folk religion to be mis-categorized as non-religious. These errors in measurement will likely cause our data to understate fragmentation.

To address this, we construct an alternative measure of fractionalization using the most reliable data available on actual religious populations in China. These data are collected by anthropologists, ethnographers and sociologists and are only available at the national level. Lai (2003) summarizes these estimates, which we show in Table 1. Column (3) shows that according to these estimates, our data may underreport Buddhism (Mahayana) by $46.6 \%$ and Christianity by $66.7 \%$ (where 
Protestants are underreported by $67 \%$ and Catholics are underreported by $100 \%)$. They also show that approximately $28.5 \%$ of Christians are Catholics.

To impute the true religious population, we first divide Christians in each village into two categories - Protestants and Catholics, where we assume that $28.5 \%$ of the Christian population is Catholic. Then, we adjust the number of religious individuals for each group by the estimated difference shown in column (3). Then, we add the category of folk religion by assuming that $20 \%$ of the total village population follow folk religious practices. The descriptive statistics for the imputed measures are shown in Table 1 columns (7)-(9). A comparison with the measures constructed from the raw NFS data show that the share of all religious population increases from approximately $5 \%$ to $26 \%$. Average fractionalization increases from approximately 0.053 to 0.2 . Figure 1 e is a histogram of the fractionalization index constructed from the imputed data across villages. Note that the cross-sectional correlation between the imputed measure of religious fractionalization and the reported measure is 0.71 and is statistically significant at the $1 \%$ level.

We re-estimate the baseline equation using the imputed measure of religious fractionalization. Table 3 column (7) shows that the estimated interaction effect of fractionalization and the introduction of elections is very similar to the baseline estimate, which we re-state in column (1). It is also statistically significant at the $5 \%$ level.

A shortcoming of our imputation exercise is that it attributes mismeasurement equally across all villages. To be cautious, we have conducted several alternative imputations where we assigned higher mis-measurement to villages that gained more from elections. For example, we can divide the villages into two groups according to whether they are in the top half or bottom half in terms of the gains in public goods from elections. We can then assume that religious composition is correctly reported by the NFS for the bottom half, but use the imputed measures for the top half, and re-estimate the baseline equation. This exercise yields very similar results as the ones presented. ${ }^{32}$

We conclude that it is highly unlikely that our main results are driven mismeasurement of the religious population.

\footnotetext{
${ }^{32}$ We tried several alternative ways of assigning mismeasurement differentially across villages. For example, we can only adjust the number of catholics upwards in the provinces known to have more Catholics (Hebei, Shaanxi, Guangxi, Gansu and Xinjiang (Lai, 2003)). Regardless of how we adjust the data, the results are always very similar. They are not reported for brevity and available upon request.
} 
Correlates of Religious Fractionalization The baseline controls of the interaction of average fractionalization and year fixed effects control for all differences between fragmented and less fragmented villages in a way that is fully flexible over time. However, to fully eliminate concerns of omitted variable bias, it is important to show that our main effect is robust to allowing these correlates to have a differential effect when elections are implemented.

The correlates, shown in Table 2, are: the average share of villagers that belong to any religion, the presence of a village temple, the number of temples historically in the same county, dummy variables for whether the village is in a hilly or mountainous area, and average pre-election household income for the 10th, 50th and 90th percentile households. ${ }^{33}$

In addition, we also control for other potentially important factors: surname fragmentation, the presence of a lineage group (e.g., the presence of a family that has an ancestral hall or family tree), the population share of the two most popular surnames, the pre-election average public goods expenditure and the pre-election average Gini coefficient, each interacted with the introduction of elections and open nominations. ${ }^{34}$

The estimates for these tests are shown in Table 7. In column (2) we omit our usual baseline controls of the interaction of the average share of villagers that belong to any religion and year fixed effects when we control for the interaction of post election and the average share of villagers that belong to any religion due to collinearity. In column (13), we control for all of these interactions in one equation (except the interaction of surname polarization because it is highly correlated with surname fractionalization, and the interaction of the average share of villagers that belong to any religion because it is highly correlated to our baseline controls that interact the same variable with all year fixed effects). Our main result is very robust and similar to the baseline, which we re-state in column (1). This provides strong evidence that our main results are not driven by spurious correlations.

There are several interesting results to note in addition to the robustness of our main results.

\footnotetext{
${ }^{33}$ Controlling for the presence of temples is motivated by the concern that our main results may be confounded by the potential influence of other dimensions of social capital. Studies in political science such as Tsai (2007) interpret village temples as plausible proxies for social capital because they are not specific to any one religion and are used to worship a range of local deities by all villagers, are funded and maintained by voluntary villagers, and are an important venue for village events such as fairs, festivals, and public discussions. In short, functioning temples are civic organizations which could be behind the differential effect of elections.

${ }^{34}$ We use surname fragmentation and the presence of lineage groups to proxy for the presence of kinship networks, which are a historically important feature of rural life and could be another dimension of social clustering.
} 
First, the interaction of surname fragmentation and the introduction of elections is small in magnitude and statistically insignificant. This suggests that religion is more important as a factor of social clustering in rural China than extended kinship networks, which confirms the claims of the qualitative literature. ${ }^{35}$ Second, pre-election income levels and income inequality (Gini) have little influence on the effect of elections. This is likely to be due to the fact that elections significantly increased income redistribution (e.g. Martinez-Bravo et al., 2012), which means that individuals can move across income groups. In other words, income does not affect the impact of elections on public goods provision most likely because the clustering of individuals into income groups is not very stable over time.

Additional Controls In Table 8 columns (2)-(4), we control for additional factors that could potentially influence the effect of elections on public goods: the interaction of a dummy variable indicating that a village is a suburb of an urban area and year fixed effects; a dummy variable indicating that the Tax and Fee Reform has been introduced; and a dummy variable for whether a village ever experienced an administrative merger interacted with year fixed effects. In column (6), we control for all of these additional variables simultaneously. In column (5), we control for a quadratic province-time trend.

The estimates show that our main result is robust to controlling for any or all of these additional controls. Similarly, we find that our results are very similar when we control for a quadratic-province time trend instead of a linear one.

Sample Selection In our context, the majority of the population is not religious. Therefore one might be concerned that our results are mainly given by the comparison between fully atheist villages and the rest. Table 9 columns (2)-(3) show that our estimates are robust to the exclusion of villages with no religious population or zero fractionalization. Similarly, public goods expenditures are not made every year, but the estimates in column (5) show that our results are robust to the exclusion of village-year observations that make no public goods expenditure. Alternatively, column (4)

\footnotetext{
${ }^{35}$ Several scholars have observed that kinship networks have declined in importance relative to other dimensions of social clustering as China modernizes (e.g., Cohen, 1992; Jiang, 1995). The decline of the importance of kinship networks has also been observed for societies that are culturally Chinese outside of the People's Republic of China. For example, in a description of villages in Taiwan during the 1970s, Deglopper, 1974, p. 65 states that "Neighborhoods... are composed of diverse populations who bear different surnames, who earn a living in different ways, and whose income ranges from high to very low. They have nothing in common except residence in an arbitrarily and rather vaguely defined area, and they do nothing in common except worship. This is because the other traditional social divisions - guilds and surnames - no longer matter today".
} 
examines a dummy variable for whether any public expenditure is made. The estimated coefficients have the same sign as the main results in column (1). Thus, our main results on expenditures recorded reflect the frequency of expenditures as well as the total amount of expenditures.

In summary, the results in this section show that the main results are extremely robust to a large set of additional controls and sensitivity checks.

\section{Conclusion}

Between 1970 and 2003, the average Polity Index for the world has increased from approximately negative two to three, meaning that the world as a whole has experienced a dramatic increase in democracy. Together with the fact that the rise in democratization has been driven by poor countries, this means that understanding the pre-conditions for successful democratization and the underlying mechanisms must rank amongst the most important questions for researchers and policymakers in development economics and political economy.

This study takes a first step in providing rigorous empirical evidence on the necessary preconditions for democratization in the context of grassroots elections in rural China and local public goods provision. The centrally determined electoral reforms in China provide a stark example of how an identical reform can have very different effects depending on the pre-existing level of voter heterogeneity. Specifically, we find that voter heterogeneity - i.e., religious fragmentation significantly reduces the gains from introducing elections.

The findings suggest that the dominant force behind the differential effects of elections in heterogeneous versus homogeneous villages was that elections increased the accountability of local governments towards villagers; this increase was larger in homogeneous villages due to their capacity to better monitor the leader. In addition, the elected village leader was forced to implement policies that reflected the underlying preferences of villagers for public goods. It is particularly noteworthy that our main result on total government public goods expenditure is entirely driven by differences in expenditure financed by villagers. Neither the introduction of elections nor its interaction with religious fragmentation has any effect on expenditure financed by other revenue sources.

A general lesson from our results is that pre-conditions are very important for determining the impact of institutional reforms. Since the influence of religion in China has been significantly 
weakened by the historical presence of a strong secular state, our estimates provide a striking illustration of a high "lower bound" on the influence of social fragmentation on elections and public goods.

Generalizations aside, we believe that understanding the determinants of the impact of electoral reforms in China is inherently important, since they are among the largest democratization reforms in history and have changed the lives of almost one billion individuals. For those interested in the social organization of rural China, our findings identify religion as an important dimension for group clustering during the post-Mao era. Indeed, we find that religion has overtaken other important traditional differences such as those across kinship groups.

There are two important caveats to keep in mind for interpreting our results. First, when attempting to extrapolate our results to other contexts, it is important to realize that the estimated sign and magnitude of the interaction effect are specific to our context. For example, we interpret the increase in public goods expenditure as beneficial because of the severe under-provision of public goods prior to the introduction of elections. Had public goods expenditure been excessive relative to demand from villagers prior to the electoral reforms (e.g., high taxation and elite rent-seeking), the increased accountability caused by elections would reduce public goods expenditure on average, and would cause the interaction with heterogeneity to be positive. Second, although the severe under-provision of public goods prior to the electoral reforms is consistent with elections improving efficiency and heterogeneity reducing it, the inability to measure demand or total public goods provision means that welfare assessments are beyond the scope of this paper. This is an important topic for future research.

More generally, this study and the data it constructs open many avenues of study. In particular, the data's comprehensive record of Chinese electoral reforms and informal institutions (e.g., religion, kinship networks), its long panel structure and its richness provide a good context for studying the interaction between formal and informal institutions in determining economic outcomes. 


\section{References}

Acemoglu, Daron and James A. Robinson, "Why did the West extend the Franchise? Democracy, Inequality and Growth in Historical Perspective," The Quarterly Journal of Economics, 2000, 115, 1167-1199.

_, Simon Johnson, James A. Robinson, and Pierre Yared, "Income and Democracy," American Economic Review, June 2008, 98 (3), 808-42.

Alesina, Alberto and Eliana La Ferrara, "Participation In Heterogeneous Communities," The Quarterly Journal of Economics, August 2000, 115 (3), 847-904.

- and Eliana La Ferrara, "Who trusts others?," Journal of Public Economics, August 2002, 85 (2), 207-234.

- and Eliana La Ferrara, "Ethnic Diversity and Economic Performance," Journal of Economic Literature, September 2005, 43 (3), 762-800.

_ Arnaud Devleeschauwer, William Easterly, Sergio Kurlat, and Romain Wacziarg, "Fractionalization," Journal of Economic Growth, June 2003, 8 (2), 155-94.

_, Reza Baqir, and William Easterly, "Public Goods and Ethnic Divisions," The Quarterly Journal of Economics, November 1999, 114 (4), 1243-1284.

Bandiera, Oriana and Gilat Levy, "Diversity and the Power of the Elites inDemocraticSocieties: A Model and a Test," STICERD - Economic Organisation and Public Policy Discussion Papers Series 018, Suntory and Toyota International Centres for Economics and Related Disciplines, LSE August 2010.

Banerjee, Abhijit and Rohini Pande, "Parochial Politics: Ethnic Preferences and Politician Corruption," Discussion Papers 6381, C.E.P.R. July 2007.

- and Rohini Somanathan, "The political economy of public goods: Some evidence from India," Journal of Development Economics, March 2007, 82 (2), 287-314.

_, Dilip Mookherjee, Kaivan Munshi, and Debraj Ray, "Inequality, Control Rights, and Rent Seeking: Sugar Cooperatives in Maharashtra," Journal of Political Economy, February 2001, 109 (1), 138-190.

_, Lakshmi Iyer, and Rohini Somanathan, Public Action for Public Goods: Theory and Evidence, Vol. 4 of Handbook of Development Economics, Elsevier Science and Technology Books,

Boix, Carles and Daniel N. Posner, "Social Capital: Explaining its Origins and Effects on Government Performance," British Journal of Political Science, 1998, 28 (04), 686-693.

Brandt, Loren and Matthew A. Turner, "The usefulness of imperfect elections: The case of village elections in rural China," Economics \& Politics, 2007, 19 (3), 453-480.

Cameron, A. Colin, Jonah B. Gelbach, and Douglas L. Miller, "Bootstrap-Based Improvements for Inference with Clustered Errors," The Review of Economics and Statistics, August 2008, $90(3), 414-427$.

Cohen, Myron L., Family Organization in China Asia: Case Studies in the Social Sciences, Sharpe, Inc., 1992. 
_ , "Religion in a State Society : China," Asia Case Studies in the Social Sciences Armonk NY ME Sharpe, 1992, p. 17ïœ31.

Dayton-Johnson, Jeff, "Determinants of collective action on the local commons: a model with evidence from Mexico," Journal of Development Economics, June 2000, 62 (1), 181-208.

Dean, K., Taoist Ritual and Popular Cults of Southeast China, Princeton University Press, 1993.

Deglopper, Donald R., Religion and Ritual in Lukang Religion and Ritual in Chinese Society, Stanford University Press,

Desmet, Klaus, Ignacio Ortuno-Ortin, and Romain Wacziarg, "The Political Economy of Ethnolinguistic Cleavages," NBER Working Papers 15360, National Bureau of Economic Research September 2009.

Duclos, Jean-Yves, Joan Esteban, and Debraj Ray, "Polarization: Concepts, Measurement, Estimation," Econometrica, 2004, 72 (6), pp. 1737-1772.

Easterly, W. and R. Levine, "Africa's growth tragedy: policies and ethnic divisions," The Quarterly Journal of Economics, 1997, 112 (4), 1203-1250.

Esteban, Joan and Debraj Ray, "On the Measurement of Polarization," Econometrica, July 1994, 62 (4), 819-51.

_ and _ , "Conflict and Distribution," Journal of Economic Theory, 1999, 87, 379-415.

_ and _ , "A Comparison of Polarization Measures," UFAE and IAE Working Papers 700.07, Unitat de Fonaments de l'Analisi Economica (UAB) and Institut d'Analisi Economica (CSIC) May 2007.

Faure, D. and H.F. Siu, Down to Earth: The Territorial Bond in South China, Stanford University Press, 1995.

Feuchtwang, S., Popular Religion in China: The Imperial Metaphor, Curzon, 2001.

Gao, Shouxian, Zhongguo zongjiao liyu [Chinese Religions and Rites]., Taipei, Taiwan: Zhidao Chuban Youxian Gongsi, 1994.

Glennerster, Rachel, Edward Miguel, and Alexander Rothenberg, "Collective Action in Diverse Sierra Leone Communities," NBER Working Papers 16196, National Bureau of Economic Research July 2010.

Gong, Zhebing and Yetao Zhou, "90 niandai Hubeisheng zongjiao xianzhuang jiqi fenxi' [The Current Situation and an Analysis of Religions in Hubei Province in the 1990s]," Shehui zhuyi yanjiu [Research on Socialism], 1999, 3, 70-73.

Gong, Zuezeng, "Zhongguo zongjiao xianzhuang ji fazhan qushi' [The Current Situation and Developmental Trend of Religions in China]," Zhongyang shehui zhuyixueyuan xuebao [Journal of Central Socialist College], 1998, 6, 24-27.

Guiso, Luigi, Paola Sapienza, and Luigi Zingales, "People's opium? Religion and economic attitudes," Journal of Monetary Economics, January 2003, 50 (1), 225-282. 
Habyarimana, James, Macartan Humphreys, Daniel N. Posner, and Jeremy M. Weinstein, "Why Does Ethnic Diversity Undermine Public Goods Provision?," The American Political Science Review, 2007, 101 (4), 709-725.

He, Kemin, "'Zhongguo de zongjiao he zongjiao zhengce' [Religions and Religious Policies in China].," Zhongwai jiaoliu [Sino-External Exchange], 1999, 3, 40-41.

Hungerman, Daniel M., "Diversity and Crowd-out: A Theory of Cold-Glow Giving," NBER Working Papers 13348, National Bureau of Economic Research, Inc August 2007.

Hunter, A. and K.K. Chan, Protestantism in Contemporary China Cambridge Studies in Ideology and Religion, Cambridge University Press, 2007.

Jiang, Lin, "Changing Kinship Structure and its Implications for Old-Age Support in Urban and Rural China," Population Studies, 1995, 49 (1), pp. 127-145.

Kelliher, Daniel, "The Chinese debate over village self-government," The China Journal, 1997, pp. 63-86.

Khwaja, Asim Ijaz, "Can good projects succeed in bad communities?," Journal of Public Economics, August 2009, 93 (7-8), 899-916.

Lai, Hongyi Harry, "The Religious Revival in China," Copenhagen Journal of Asian Studies, 2003, 18, 40-64.

Le, Guoan and Guoping Jiang, "Fengjian mixin yu shehui wending' [Feudal Superstitions and Social Stability]," Gangnan shifan xueyuan xuebao [Journal of the Southern Jiangxi Normal College], 1998, 1, 73-76.

Lipset, Seymour Martin, "Some Social Requisites of Democracy: Economic Development and Political Legitimacy," The American Political Science Review, 1959, 53 (1), pp. 69-105.

Lizzeri, Alessandro and Nicola Persico, "Why did the Elites Extend the Suffrage? Democracy and the Scope of Government with an Application to Britain's "Age of Reform"," The Quarterly Journal of Economics, 2004, 119, 707-765.

Luo, Renfu, Linxiu Zhang, Jikun Huang, and Scott Rozelle, "Village Elections, Public Goods Investments and Pork Barrel Politics, Chinese-style," Journal of Development Studies, 2010, $46(4), 662-684$.

Luo, W., Christianity in China, China Intercontinental Press, 2004.

Luttmer, Erzo F. P., "Group Loyalty and the Taste for Redistribution," Journal of Political Economy, June 2001, 109 (3), 500-528.

MacInnis, D.E., Religion in China today: policy and practice, Orbis Books, 1989.

Madsen, Richard, "Religious Renewal," in Richard Madsen Perry Link and Paul Pickowicz, eds., Unofficial China: Popular Culture and Thought in the People's Republic, Boulder, Colorado: Westview Press, 1989, pp. 103-120.

- and Linzhu Fan, The Catholic Pilgrimage to Sheshan The Politics of Religion in Modern China: Making Religion Making the State, Stanford University Press, 
Martinez-Bravo, Monica, Gerard Padro-Miquel, Nancy Qian, and Yang Yao, "The Effect of Democratization on Public Goods and Redistribution: Evidence from China," Yale Working Paper, 2012.

Miguel, Edward and Mary Kay Gugerty, "Ethnic diversity, social sanctions, and public goods in Kenya," Journal of Public Economics, December 2005, 89 (11-12), 2325-2368.

Montalvo, Jose and Marta Reynal-Querol, "Ethnic Diversity and Economic Development," Journal of Development Economics, 2003, 76, 293-323.

Mu, Ren and Xiaobo Zhang, "The Role of Elected and Appointed Village Leaders in the Allocation of Public Resources: Evidence from a Low-Income Region in China," IFPRI Working Paper http://www.ifpri.org/publication/role-elected-and-appointed-village-leadersallocation-public-resources, International Food and Policy Research Institute 2011.

Munshi, Kaivan and Mark Rosenzweig, "The Efficacy of Parochial Politics: Caste, Commitment, and Competence in Indian Local Governments," NBER Working Papers 14335, National Bureau of Economic Research September 2008.

- and Nicholas Wilson, "Identity and Mobility: Historical Fractionalization, Parochial Institutions, and Occupational Choice in the American Midwest," Department of Economics Working Papers 2010-22, Williams College August 2010.

O’Brien, Kevin J., "Implementing Political Reform in China's Villages," Australian Journal of Chinese Affairs, 1994, (32), 33 - 59.

_ and Lianjiang Li, "The Struggle over Village Elections," in Merle Goldman and Roderick MacFarquhar, eds., The paradox of China's post-Mao reforms, Cambridge, MA: Harvard University Press, 1999.

Oi, Jean and Scott Rozelle, "Elections and power: The locus of decision-making in Chinese villages," The China Quarterly, 2000, 162, 513-539.

Okten, Cagla and Una Okonkwo Osili, "Contributions in heterogeneous communities: Evidence from Indonesia," Journal of Population Economics, December 2004, 17 (4), 603-626.

PadroiMiquel, Gerard, "The Control of Politicians in Divided Societies: The Politics of Fear," The Review of Economic Studies, 2007, 74, 1259-1274.

Rozelle, Scott, "Decision-Making in China's Rural Economy: The Linkages between Village Leaders and Farm Households," The China Quarterly, 1994, (137), 99-124.

Singhal, Monica and Benjamin A. Olken, "Informal Taxation," Technical Report 2009.

Siu, Helen F., "Recycling Ritualst," in Richard Madsen Perry Link and Paul Pickowicz, eds., Unofficial China: Popular Culture and Thought in the People's Republic, Boulder, Colorado: Westview Press, 1989, pp. 121-37.

Sweeten, A.R., Christianity in rural China: conflict and accommodation in Jiangxi Province, 1860-1900 Michigan monographs in Chinese studies, Center for Chinese Studies, University of Michigan, 2001.

Tsai, Lily Lee, "Cadres, Temple and Lineage Institutions, and Governance in Rural China," The China Journal, 2002, (48), 1-27. 
_, Accountability without Democracy: Solidary Groups and Public Goods Provision in Rural China, New York, NY: Cambridge University Press, 2007.

Unger, Jonathan, The Nature of Chinese Politics: From Mao to Jiang, Cambridge, MA: M.E. Sharpe, 2002.

Vigdor, J.L., "Community Composition and Collective Action: Analyzing Initial Mail Response to the 2000 census," Review of Economics and Statistics, 2004, 86 (1), 303-312.

Weber, M., The religion of China: Confucianism and Taoism Free Press paperback, Free Press, 1968.

Whiting, Susan, "Contract Incentives and Market Discipline in China's Rural Industrial Sector," in John McMillan and Barry Naughton, eds., Reforming Asian Socialism, The Growth of Market Institutions, Ann Arbor: University of Michigan Press, 1996.

Yang, C.K., Religion in Chinese Society: A Study of Contemporary Social Functions of Religion and Some of Their Historical Factors, University of California Press, 1961.

Youngliang, Du, Jianming yinghan, hanying shijie zongjiao cidian /A Concise English-Chinese and Chineseï̋œEnglish Dictionary of World Religious Terms], Zhongguo Duiwai Fanyi Chuban Gongsi, 1994.

Zhang, Xiaobo, Shenggen Fan, Linxiu Zhang, and Jikun Huang, "Local governance and public goods provision in rural China," Journal of Public Economics, 2004, 88, 2857-2871.

Zhu, Yulie, Jinri zhongguo zongjiao [Religion in Today's China], Beijing: Jinri Zhongguo chubanshe, 1994. 
Table 1: Statistics on Religious Populations in China

\begin{tabular}{|c|c|c|c|c|c|c|c|c|c|}
\hline & \multicolumn{3}{|c|}{$\begin{array}{l}\text { Share of Religious Population } \\
\text { per Village (NFS, 1986-2005) }\end{array}$} & \multicolumn{3}{|c|}{$\begin{array}{l}\text { Aggregate Religious Population in } \\
\text { China (Lai, 2003) }\end{array}$} & \multicolumn{3}{|c|}{$\begin{array}{l}\text { Imputed Measures of the Share } \\
\text { of Religious Population per } \\
\text { Village (Calculated by Authors) }\end{array}$} \\
\hline & $(1)$ & $(2)$ & (3) & $(4)$ & (5) & (6) & (7) & $(8)$ & (9) \\
\hline & Obs & Mean & Std. Dev. & Official & Non-Official & $\%$ Difference & Obs & Mean & Std. Dev. \\
\hline Mahayana Buddhism (Han) & 4340 & 0.022 & 0.086 & 90.5 & 132.7 & $46.63 \%$ & 4340 & 0.028 & 0.104 \\
\hline Daoism & 4340 & 0.003 & 0.010 & 3 & 3 & $0.00 \%$ & 4340 & 0.003 & 0.010 \\
\hline Islam & 4340 & 0.017 & 0.094 & 20.3 & 20 & $-1.48 \%$ & 4340 & 0.015 & 0.089 \\
\hline Christian & 4340 & 0.008 & 0.030 & 21 & 35 & $66.67 \%$ & & & \\
\hline Protestanism & & & & 16 & 25 & $56.25 \%$ & 4340 & 0.199 & 0.007 \\
\hline Catholicism & & & & 5 & 10 & $100.00 \%$ & 4340 & 0.004 & 0.011 \\
\hline Folk Religions & & & & & & & 4340 & 0.200 & 0.000 \\
\hline All Religions & 4340 & 0.050 & 0.146 & & & & 4340 & 0.050 & 0.146 \\
\hline Non Religious & 4340 & 0.950 & 0.153 & & & & 4340 & 0.723 & 0.161 \\
\hline Religious Fractionalization & 4340 & 0.053 & 0.105 & & & & 4340 & 0.202 & 0.072 \\
\hline Religious Polarization & 4340 & 0.101 & 0.193 & & & & 4340 & 0.667 & 0.043 \\
\hline
\end{tabular}

Table 2: The Correlates of Religious Fragmentation

\begin{tabular}{lc}
\hline \hline & $\begin{array}{c}\text { Religious } \\
\text { Fractionalization }\end{array}$ \\
\hline Religious Polarization & $0.9952^{\star}$ \\
Village Population & $0.1881^{*}$ \\
Share of Religious Population (Any Religion) & $0.8445^{\star}$ \\
Fraction of Highschool Graduates & -0.0413 \\
& \\
Avg. Pre-Election Pub Goods Exp & 0.0229 \\
$\quad$ Financed by Villagers & 0.0347 \\
Avg. Pre-Election Income -- 10th Percentile & $0.1756^{\star}$ \\
Avg. Pre-Election Income -- 50th Percentile & $0.1974^{*}$ \\
Avg. Pre-Election Income -- 90th Percentile & $0.2367^{\star}$ \\
Avg. Pre-Election Gini & 0.0588 \\
& \\
Year of 1st Election & -0.0556 \\
Year of 1st Haixuan & 0.1306 \\
& \\
Fractionalization of Surnames & -0.0731 \\
Population Share of the Two Largest Surnames & -0.023 \\
Presence of Village Temple & $0.2048^{\star}$ \\
Number of Temples in County in 1820 & $0.1637^{\star}$ \\
Plain & 0.056 \\
Hilly & 0.0166 \\
Mountainous & -0.0799 \\
\hline
\end{tabular}

Observations are at the village level. * indicates that the correlations are statistically significant at the $5 \%$ level. 


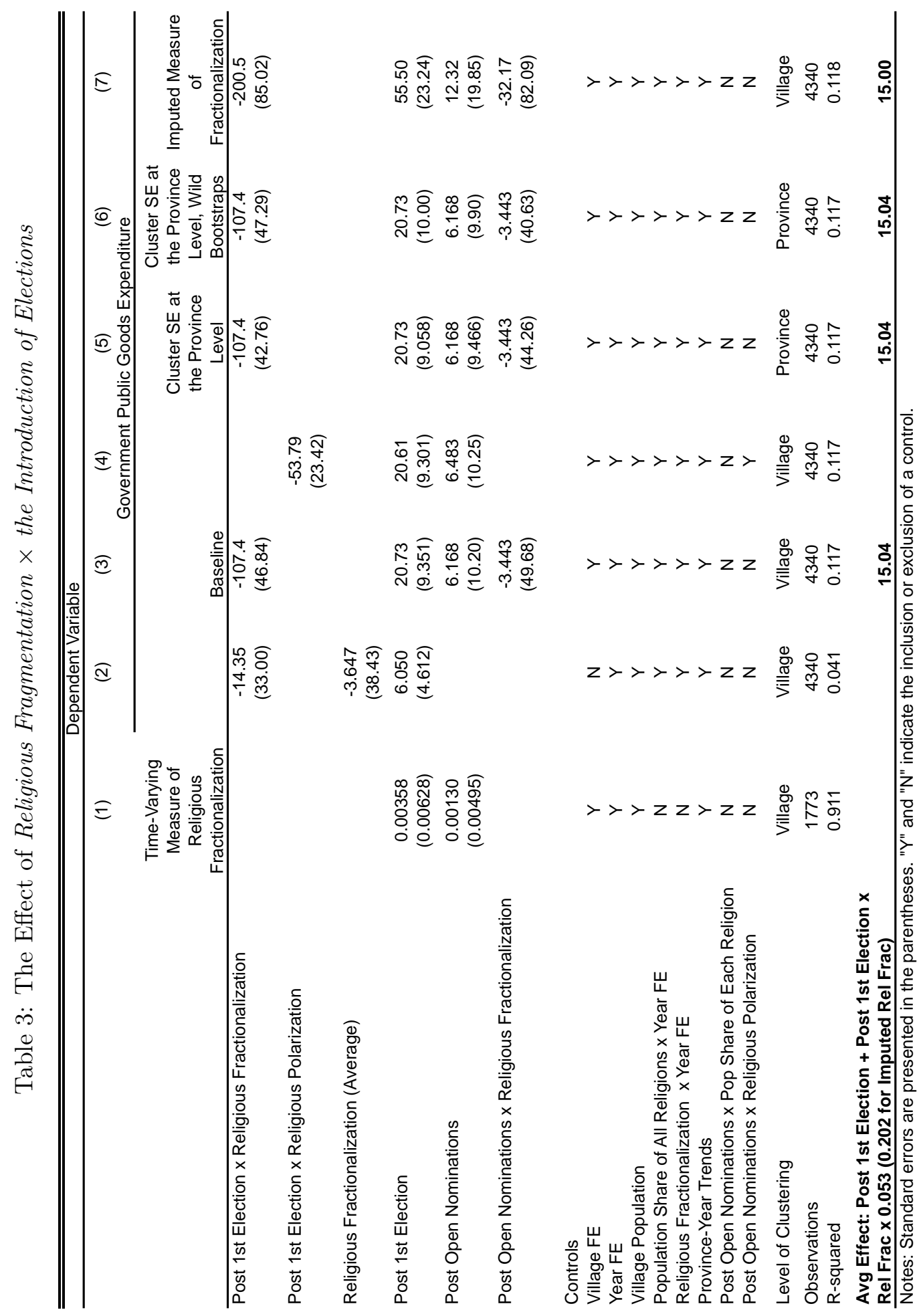




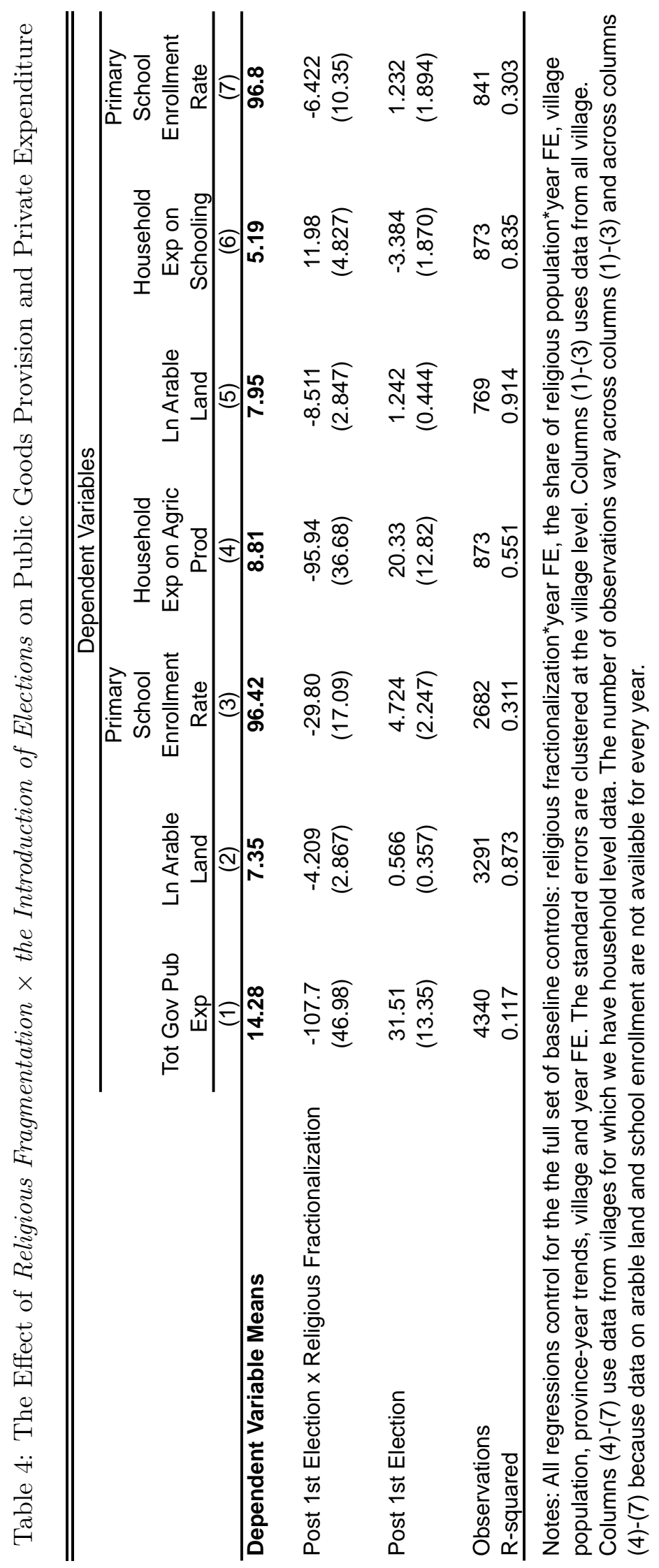


Table 5: The Effect of Religious Fragmentation $\times$ the Introduction of Elections on Public Goods Expenditure from Villagers and Election Quality

\begin{tabular}{|c|c|c|c|c|c|}
\hline & \multicolumn{5}{|c|}{ Dependent Variables } \\
\hline & \multicolumn{3}{|c|}{$\begin{array}{c}\text { Government Public Goods Exp by } \\
\text { Source of Financing }\end{array}$} & \multirow{2}{*}{$\begin{array}{l}\text { Household Tax } \\
\text { Payments to } \\
\text { Village, } \\
\text { Township and } \\
\text { County } \\
\text { Governments } \\
\text { (4) }\end{array}$} & \multirow{2}{*}{$\begin{array}{l}\text { Voluntary } \\
\text { Social } \\
\text { Organization } \\
\text { Dummy } \\
\text { (5) }\end{array}$} \\
\hline & $\begin{array}{l}\text { All } \\
(1)\end{array}$ & $\begin{array}{c}\text { Villagers } \\
\text { (2) }\end{array}$ & $\begin{array}{c}\text { Non-Villagers } \\
\text { (3) }\end{array}$ & & \\
\hline Dep Var Mean & 14.279 & 9.769 & 4.422 & 176.19 & 0.143 \\
\hline $\begin{array}{l}\text { Post } 1 \text { st Election } \\
\text { x Religious Fractionalization }\end{array}$ & $\begin{array}{l}-107.4 \\
(46.84)\end{array}$ & $\begin{array}{l}-97.20 \\
(46.39)\end{array}$ & $\begin{array}{l}-11.53 \\
(11.46)\end{array}$ & $\begin{array}{l}-54.99 \\
(138.0)\end{array}$ & $\begin{array}{l}-0.777 \\
(0.612)\end{array}$ \\
\hline Post 1st Election & $\begin{array}{l}20.73 \\
(9.351)\end{array}$ & $\begin{array}{l}21.09 \\
(9.761)\end{array}$ & $\begin{array}{l}-0.159 \\
(2.052)\end{array}$ & $\begin{array}{l}32.71 \\
(24.00)\end{array}$ & $\begin{array}{c}0.0157 \\
(0.0269)\end{array}$ \\
\hline $\begin{array}{l}\text { Observations } \\
\text { R-squared }\end{array}$ & $\begin{array}{l}4340 \\
0.117\end{array}$ & $\begin{array}{l}4340 \\
0.107\end{array}$ & $\begin{array}{l}4340 \\
0.076\end{array}$ & $\begin{array}{l}1300 \\
0.573\end{array}$ & $\begin{array}{l}3900 \\
0.805\end{array}$ \\
\hline
\end{tabular}

Notes: All regressions control for the the full set of baseline controls: religious fractionalization ${ }^{*}$ year FE, the share of religious population*year FE, village population, province-year trends, village and year FE. The standard errors are clustered at the village level. Columns (1)-(3) and (5) use data from the full sample of villages. The number of observations in column (5) are fewer due to missing values. Column (4) uses data from the villages for which we have househol-level data. 


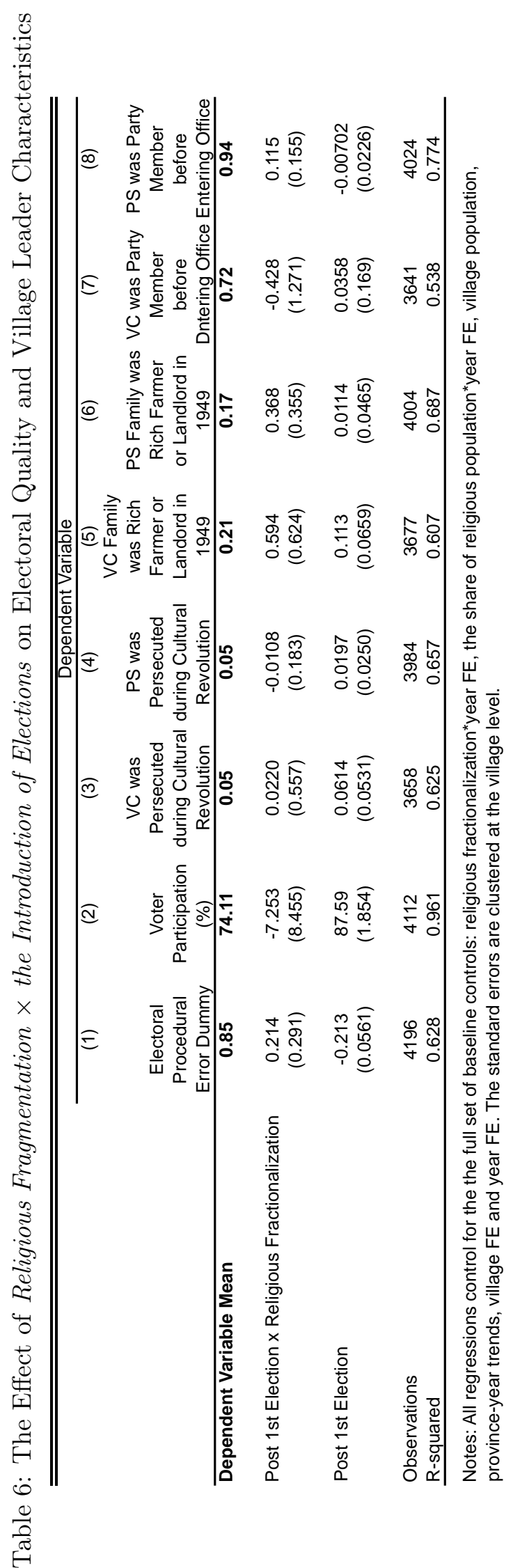




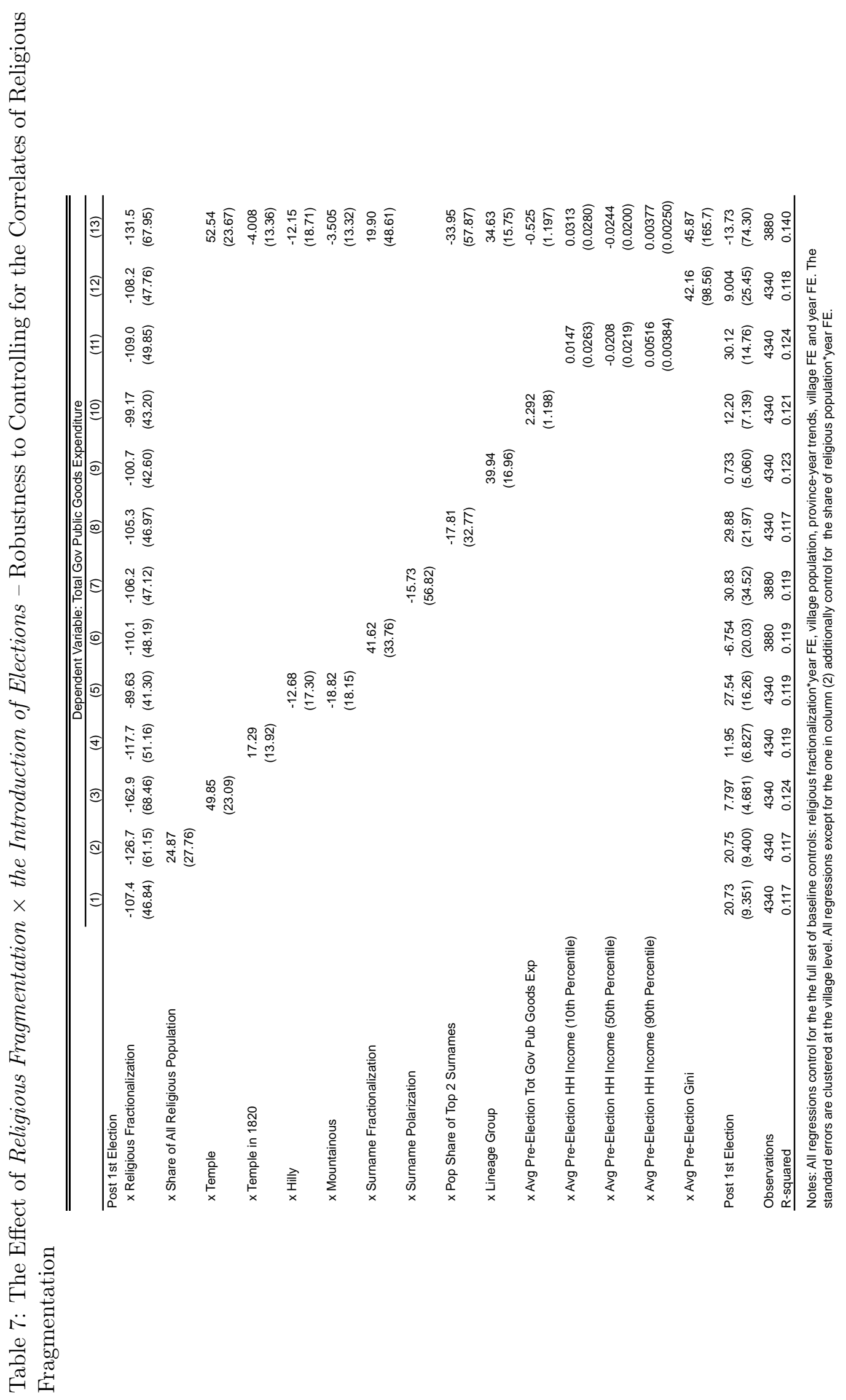




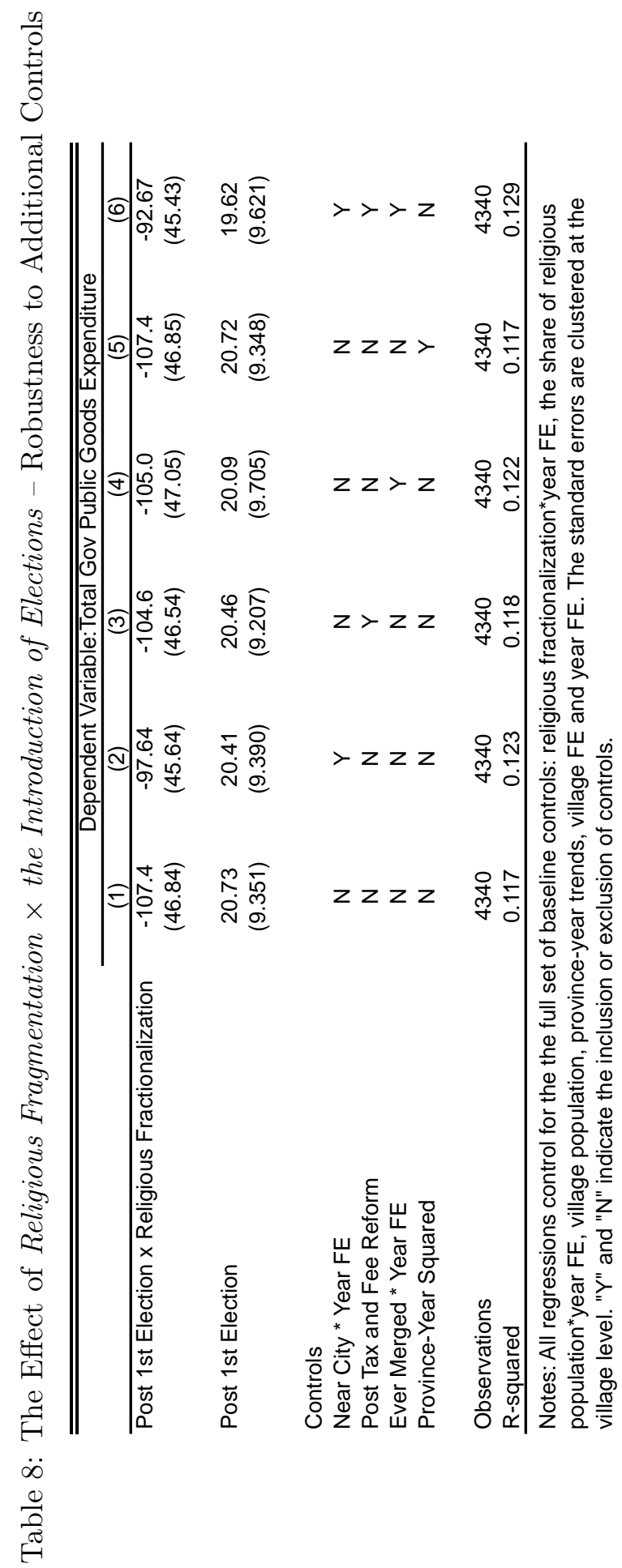




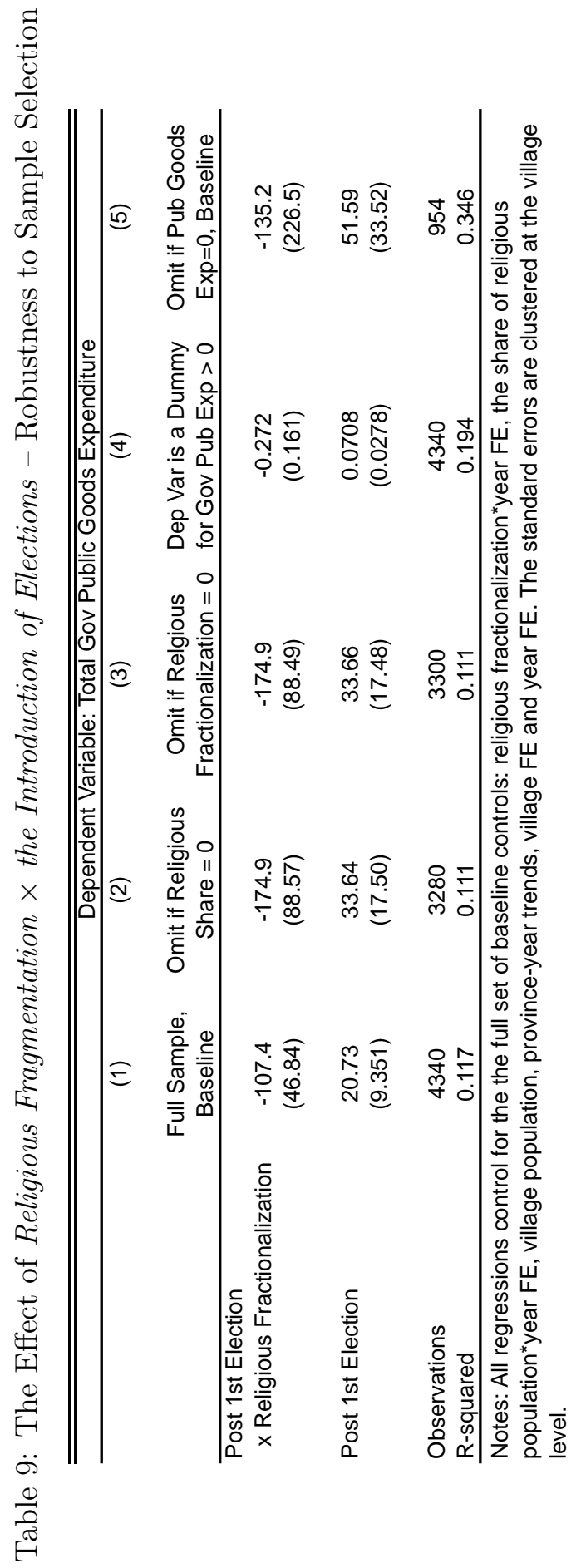


Figure 1: Histograms of Religious Fractionalization Across Villages

(a) Raw Data - Full Sample

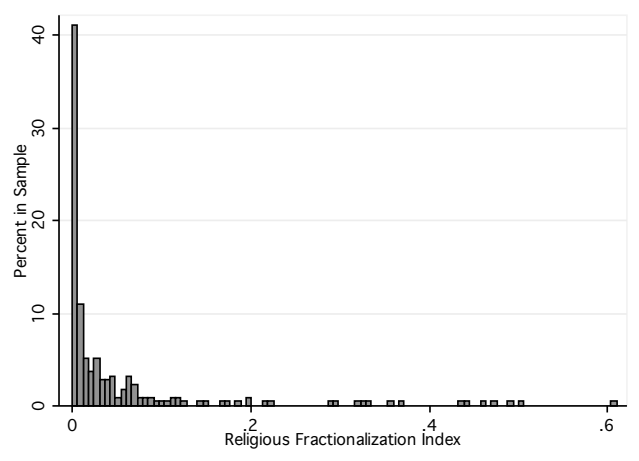

(c) Raw Data - Top Half

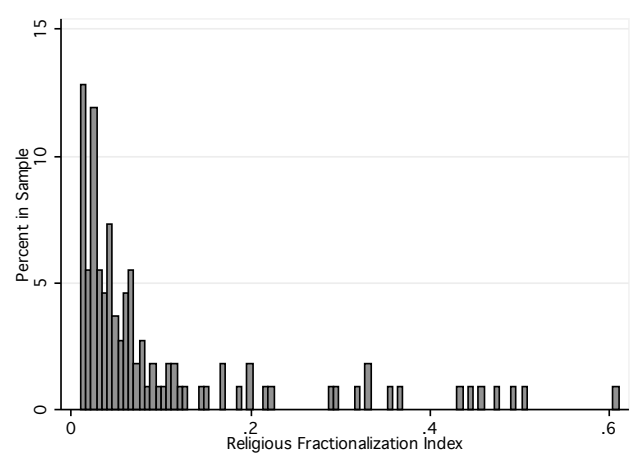

(e) Imputed Data - Full Sample

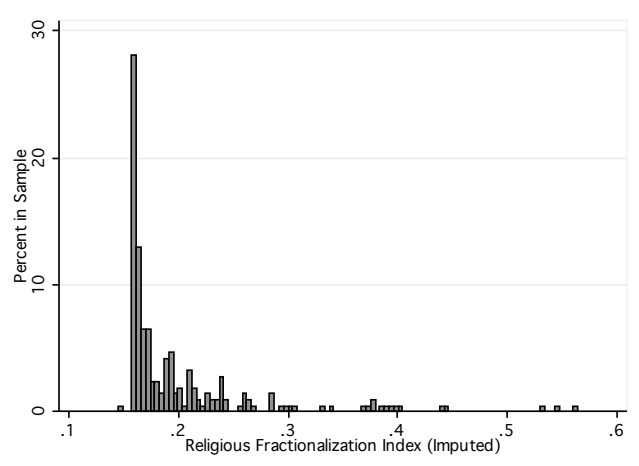

(b) Raw Data - Bottom Half

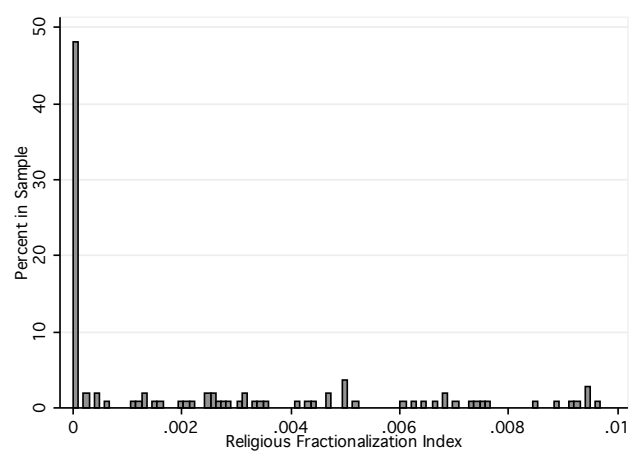

(d) Raw Data - Top Quarter

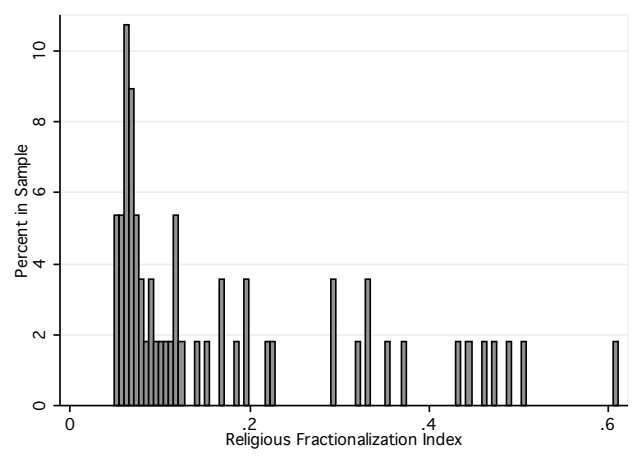


Figure 2: The Estimated Effects on Government Public Goods Expenditure for Each Year Since the First Election

(a) The Coefficients for Villages where Fractionalization $=0$ and the differential Effects between Villages where Fractionalization $=0$ and Fractionalization $=1$

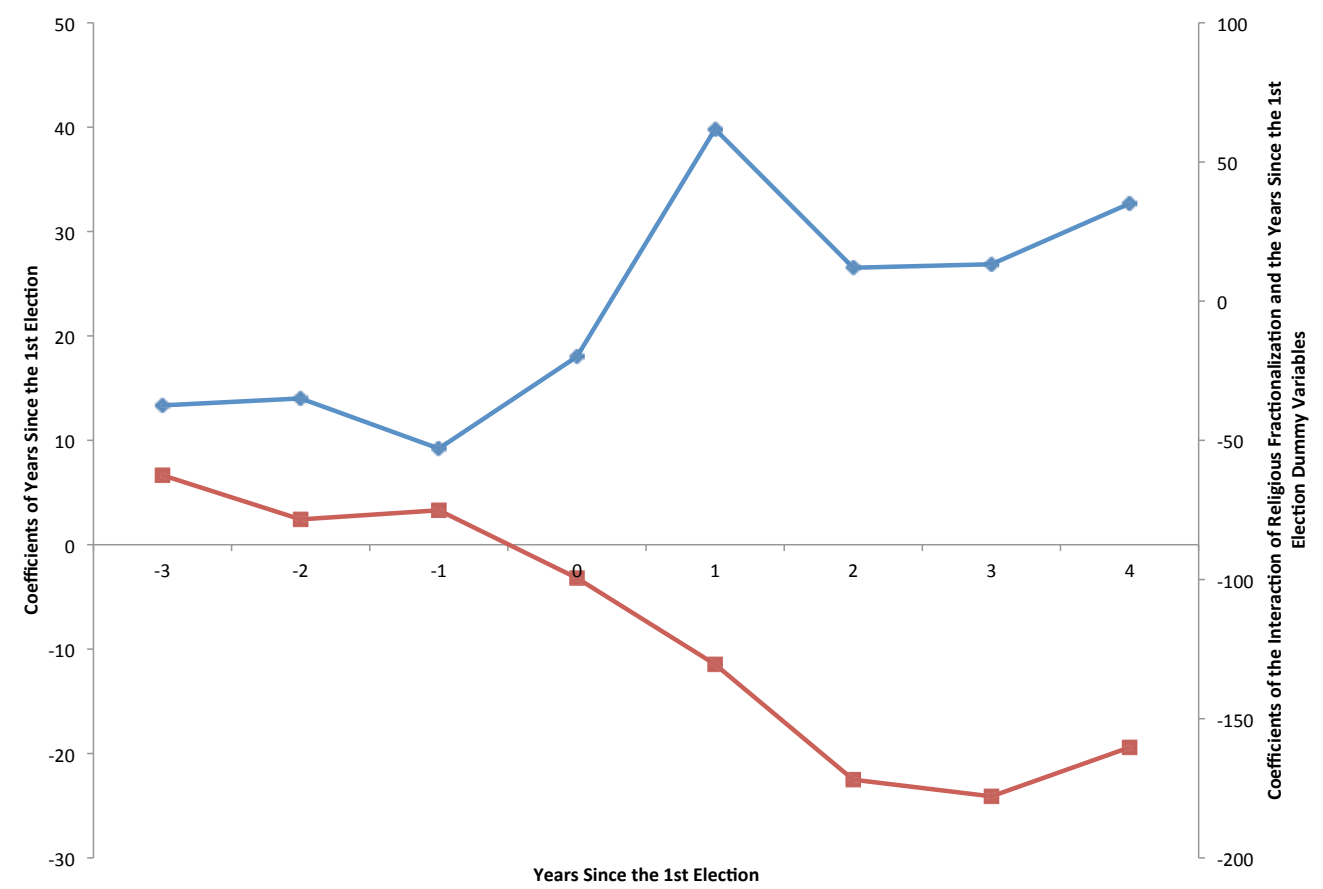

(b) The Effect for the Average Village with Fractionalization $=0.053$

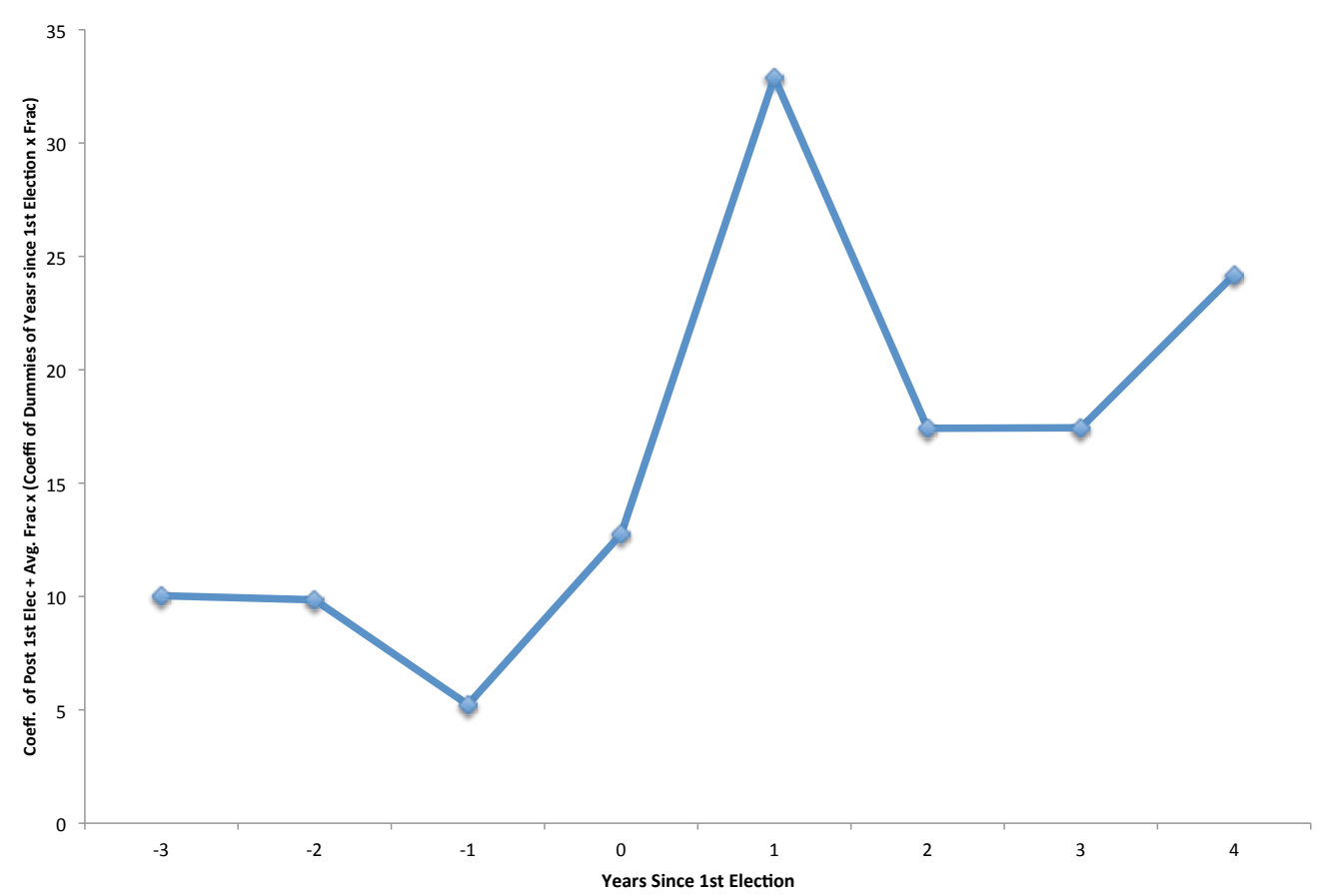


Table A.1: Descriptive Statistics

\begin{tabular}{lcccc}
\hline \hline & $(1)$ & $(2)$ & $(3)$ & $(4)$ \\
& Source & Obs. & Mean & Std. Dev. \\
\hline Village \# Households & NFS & 4340 & 414.19 & 275.47 \\
Fraction of Highschool Graduates & NFS & 1882 & 0.05 & 0.06 \\
& & & & \\
Avg. Pre-Election Pub Goods Exp (10.000 RMB) & VDS & 4340 & 14.28 & 135.47 \\
$\quad$ Financed by Villagers & VDS & 4340 & 9.77 & 119.29 \\
& & & & \\
Avg Public Goods & VDS & 4340 & 14.28 & 135.47 \\
$\quad$ Schools & VDS & 4340 & 0.02 & 0.35 \\
$\quad$ Roads and Sanitation & VDS & 4340 & 5.07 & 88.21 \\
$\quad$ Electricity & VDS & 4340 & 0.73 & 7.85 \\
$\quad$ Irrigation & VDS & 4340 & 3.43 & 66.13 \\
$\quad$ Planting Trees and the Environment & VDS & 4340 & 0.32 & 12.43 \\
Others & VDS & 4340 & 2.72 & 49.70 \\
& & & & \\
Avg. Pre-Election Income -- 10th Percentile & NFS & 3778 & 5080.40 & 3638.01 \\
Avg. Pre-Election Income -- 50th Percentile & NFS & 3778 & 10512.98 & 8365.71 \\
Avg. Pre-Election Income -- 90th Percentile & NFS & 3778 & 24427.83 & 36802.13 \\
Gini & NFS & 3550 & 0.28 & 0.08 \\
& & & & \\
Year of 1st Election & VDS & 4340 & 1988.51 & 5.24 \\
Year of 1st Haixuan & VDS & 2780 & 1997.45 & 5.26 \\
\hline The full sample uses a panel of 217 villages for the years 1982-2005. Observations vary \\
across variables due to data limitations. & & & & \\
& & &
\end{tabular}

Table A.2: The Effect of Religious Fragmentation for Each Years Since the Introduction of Elections

\begin{tabular}{|c|c|c|c|c|c|}
\hline \multicolumn{6}{|c|}{ Dependent Variable: Gov Public Goods Exp } \\
\hline & $(1)$ & $(2)$ & & (3) & $(4)$ \\
\hline & coef & se & & coef & se \\
\hline Post 1st Election & & & Post 1st Open Nomination & & \\
\hline$x$ Years Since Election $=-3$ & -62.55 & (76.34) & $x$ Years Since Open Nomination $=-3$ & -16.97 & (33.58) \\
\hline$x$ Years Since Election $=-2$ & -78.39 & (73.84) & $x$ Years Since Open Nomination $=-2$ & -25.39 & (41.66) \\
\hline$x$ Years Since Election $=-1$ & -75.14 & (78.70) & $x$ Years Since Open Nomination $=-1$ & -67.6 & (95.77) \\
\hline$x$ Years Since Election $=0$ & -115.1 & (74.26) & $x$ Years Since Open Nomination $=0$ & 5.954 & (44.36) \\
\hline $\mathrm{x}$ Years Since Election $=1$ & -99.48 & (71.88) & x Years Since Open Nomination $=1$ & 46.63 & (70.95) \\
\hline$x$ Years Since Election $=2$ & -171.9 & (81.02) & x Years Since Open Nomination $=2$ & 29.08 & (53.39) \\
\hline$x$ Years Since Election $=3$ & -177.9 & (97.91) & x Years Since Open Nomination $=3$ & -90.48 & (145.0) \\
\hline $\mathrm{x}$ Years Since Election $=4$ & -160.3 & (92.04) & x Years Since Open Nomination $=4$ & -58.32 & $(102.6)$ \\
\hline Years Since Election $=-3$ & 13.35 & $(9.090)$ & Years Since Open Nomination $=-3$ & -4.112 & (5.267) \\
\hline Years Since Election $=-2$ & 14.01 & $(9.924)$ & Years Since Open Nomination $=-2$ & -5.872 & $(4.863)$ \\
\hline Years Since Election $=-1$ & 9.211 & (11.47) & Years Since Open Nomination $=-1$ & 10.69 & (22.40) \\
\hline Years Since Election $=0$ & 18.03 & (11.49) & Years Since Open Nomination $=0$ & -7.774 & $(5.230)$ \\
\hline Years Since Election $=1$ & 39.81 & (26.62) & Years Since Open Nomination $=1$ & 15.92 & (28.42) \\
\hline Years Since Election $=2$ & 26.53 & (13.05) & Years Since Open Nomination $=2$ & -16.61 & (9.973) \\
\hline Years Since Election $=3$ & 26.87 & (17.51) & Years Since Open Nomination $=3$ & 26.85 & (26.11) \\
\hline Years Since Election $=4$ & 32.68 & (17.92) & Years Since Open Nomination $=4$ & -2.444 & (18.15) \\
\hline Observations & & & 4340 & & \\
\hline R-squared & & & 0.121 & & \\
\hline
\end{tabular}

Notes: The regression controls for the the full set of baseline controls: religious fractionalization*year FE, the share of religious population*year FE, village population, province-year trends, and year FE. The standard errors are clustered at the village level. 
Figure A.1: Fractionalization versus Polarization - Using Raw Data

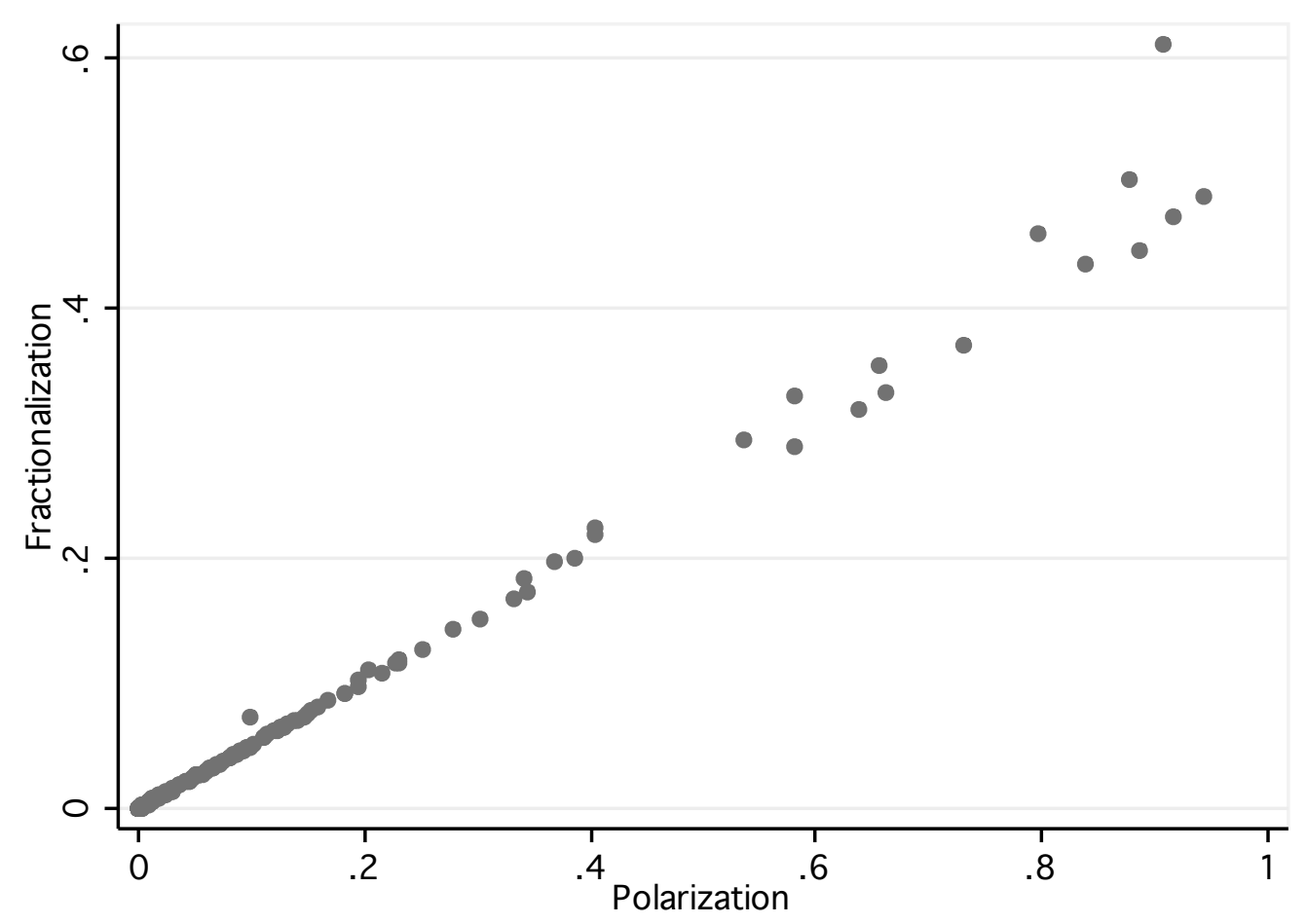

